\title{
Increased Excitatory Synaptic Input to Granule Cells from Hilar and CA3 Regions in a Rat Model of Temporal Lobe Epilepsy
}

\author{
Wei Zhang, ${ }^{1}$ John R. Huguenard, ${ }^{2}$ and Paul S. Buckmaster ${ }^{1,2}$ \\ Departments of ${ }^{1}$ Comparative Medicine and ${ }^{2}$ Neurology and Neurological Sciences, Stanford University, Stanford, California 94305
}

\begin{abstract}
One potential mechanism of temporal lobe epilepsy is recurrent excitation of dentate granule cells through aberrant sprouting of their axons (mossy fibers), which is found in many patients and animal models. However, correlations between the extent of mossy fiber sprouting and seizure frequency are weak. Additional potential sources of granule cell recurrent excitation that would not have been detected by markers of mossy fiber sprouting in previous studies include surviving mossy cells and proximal CA3 pyramidal cells. To test those possibilities in hippocampal slices from epileptic pilocarpine-treated rats, laser-scanning glutamate uncaging was used to randomly and focally activate neurons in the granule cell layer, hilus, and proximal CA3 pyramidal cell layer while measuring evoked EPSCs in normotopic granule cells. Consistent with mossy fiber sprouting, a higher proportion of glutamate-uncaging spots in the granule cell layer evoked EPSCs in epileptic rats compared with controls. In addition, stimulation spots in the hilus and proximal CA3 pyramidal cell layer were more likely to evoke EPSCs in epileptic rats, despite significant neuron loss in those regions. Furthermore, synaptic strength of recurrent excitatory inputs to granule cells from CA3 pyramidal cells and other granule cells was increased in epileptic rats. These findings reveal substantial levels of excessive, recurrent, excitatory synaptic input to granule cells from neurons in the hilus and proximal CA3 field. The aberrant development of these additional positive-feedback circuits might contribute to epileptogenesis in temporal lobe epilepsy.
\end{abstract}

\section{Introduction}

Recurrent, excitatory circuits can generate excessive positivefeedback and seizure activity (Wong et al., 1986), and their aberrant development might be epileptogenic. In many patients with temporal lobe epilepsy (de Lanerolle et al., 1989; Sutula et al., 1989; Houser et al., 1990) and after epileptogenic injuries in animal models (Nadler et al., 1980; Lemos and Cavalheiro, 1995; Golarai et al., 2001; Santhakumar et al., 2001), granule cell axons (mossy fibers) grow from their normal location in the hilus into the molecular layer where they form synapses (Babb et al., 1991; Represa et al., 1993; Zhang and Houser, 1999; Buckmaster et al., 2002) and excite neighboring granule cells (Wuarin and Dudek, 1996; Molnár and Nadler, 1999; Lynch and Sutula, 2000; Scharfman et al., 2003). Some studies found positive correlations between anatomical measures of mossy fiber sprouting and seizure frequency (Mathern et al., 1993, 1997; Lemos and Cavalheiro, 1995; Wenzel et al., 2000b; Pitkänen et al., 2005; Kharatishvili et al., 2006), but most have not (Cronin and Dudek, 1988; Masu-

\footnotetext{
Received Oct. 23, 2011; revised Nov. 28, 2011; accepted Dec. 3, 2011.

Author contributions: W.Z., J.R.H., and P.S.B. designed research; W.Z., J.R.H., and P.S.B. performed research; J.R.H. contributed unpublished reagents/analytic tools; W.Z. and P.S.B. analyzed data; W.Z. and P.S.B. wrote the paper.

This work was supported by National Institute of Neurological Disorders and Stroke-National Institutes of Health. We are grateful to Dr. David Prince for providing access to equipment.

Correspondence should be addressed to Paul S. Buckmaster, Department of Comparative Medicine, 300 Pasteur Drive, R321 Edwards Building, Stanford University, Stanford, CA 94305-5342. E-mail: psb@stanford.edu.

DOI:10.1523/JNEUROSCI.5342-11.2012

Copyright $\odot 2012$ the authors $\quad 0270-6474 / 12 / 321183-14 \$ 15.00 / 0$
}

kawa et al., 1992; Sloviter, 1992; Mello et al., 1993; Buckmaster and Dudek, 1997; Spencer et al., 1999; Timofeeva and Peterson, 1999; Pitkänen et al., 2000; Wenzel et al., 2000a; Gorter et al., 2001; Lehmann et al., 2001; Nissinen et al., 2001; Zhang et al., 2002; Raol et al., 2003; Jung et al., 2004; Lynd-Balta et al., 2004; Williams et al., 2004; Harvey and Sloviter, 2005; Rao et al., 2006; Kadam and Dudek, 2007; Buckmaster and Lew, 2011). Lack of correlation might be attributable to other aberrant, recurrent, excitatory circuits that activate granule cells but are not detected by mossy fiber labeling techniques.

Additional possible sources of positive feedback to granule cells include surviving mossy cells and proximal CA3 pyramidal cells. Normally, mossy cells receive excitatory synaptic input from nearby granule cells (Scharfman et al., 1990; Sík et al., 2006), but most of their axon projections are to distant septotemporal levels (Buckmaster et al., 1996) leaving relatively few recurrent synapses with granule cells in hippocampal slices (Buckmaster et al., 1992; Scharfman, 1995). However, after lesioning entorhinal input to the dentate gyrus, mossy cell axons sprout and synapse with granule cells (Del Turco et al., 2003; Prang et al., 2003), which raises the possibility of synaptic reorganization under other conditions, including temporal lobe epilepsy. Proximal CA3 pyramidal cells in control animals receive excitatory synaptic input from granule cells and occasionally extend axon collaterals retrogradely into the inner molecular layer of the dentate gyrus where they could synapse with granule cell dendrites ( $\mathrm{Li}$ et al., 1994). In epileptic rats, tracer injections reveal more axon projections from proximal CA3 to the dentate molecular layer 
(Siddiqui and Joseph, 2005). Together, these findings suggest that, in temporal lobe epilepsy, granule cells might receive excessive recurrent excitation through surviving mossy cells and proximal CA3 pyramidal cells, but functional evidence is lacking. We used laser-scanning photo-uncaging of glutamate to evaluate potential contributions of hilar and CA3 neurons to recurrent excitation of granule cells in epileptic pilocarpine-treated rats.

\section{Materials and Methods}

Animals. All experiments were performed in accordance with the National Institutes of Health Guide for the Care and Use of Laboratory Animals and approved by the Stanford University Institutional Animal Care and Use Committee. Male Sprague Dawley rats (Harlan) were treated with pilocarpine when they were $27-41 \mathrm{~d}$ of age, as described previously (Buckmaster, 2004). Briefly, pilocarpine (380 mg/kg, i.p.) was administered $20 \mathrm{~min}$ after atropine methyl bromide $(5 \mathrm{mg} / \mathrm{kg}$, i.p.). Diazepam (Hospira) was administered ( $10 \mathrm{mg} / \mathrm{kg}$, i.p.) $2 \mathrm{~h}$ after the onset of stage 3 or greater seizures (Racine, 1972) and repeated as necessary over the next $24 \mathrm{~h}$ to suppress convulsions. Control rats included animals that were treated identically but did not develop status epilepticus $(n=13)$ and naive rats $(n=10)$. There were no significant differences in naive and pilocarpine-treated control rats, so data were combined. Control rats were $65 \pm 3 \mathrm{~d}$ of age (mean \pm SEM; range, $47-100 \mathrm{~d}$ ) when slices were prepared. Epileptic rats $(n=32)$ were used for slice experiments when they were $72 \pm 2 \mathrm{~d}$ of age (range, 51-91 d), $38 \pm 2 \mathrm{~d}$ (range, 17-57 d) after pilocarpine-induced status epilepticus. Video monitoring, which began at least $10 \mathrm{~d}$ after pilocarpine treatment, verified spontaneous motor convulsions in all epileptic rats. No controls were observed to have spontaneous seizures.

Slice preparation. Animals were deeply anesthetized with urethane (1.5 $\mathrm{g} / \mathrm{kg}$, i.p.) and decapitated. Tissue blocks including the dentate gyrus were removed rapidly and stored for $3 \mathrm{~min}$ in modified ice-cold artificial CSF ( $\mathrm{mACSF}$ ) containing the following (in $\mathrm{mm}$ ): 230 sucrose, $2.5 \mathrm{KCl}, 10$ $\mathrm{MgSO}_{4}, 1.25 \mathrm{NaH}_{2} \mathrm{PO}_{4}, 26 \mathrm{NaHCO}_{3}, 2.5 \mathrm{CaCl}_{2}$, and 10 glucose. Horizontal slices $(400 \mu \mathrm{m})$ were prepared with a microslicer (Leica; VT1000S). Slices were incubated at $32^{\circ} \mathrm{C}$ for $30 \mathrm{~min}$ in a submersion-type holding chamber that contained 50\% mACSF and 50\% normal ACSF, which consisted of the following (in $\mathrm{mm}$ ): $126 \mathrm{NaCl}, 3 \mathrm{KCl}, 2 \mathrm{MgSO}_{4}$, $1.25 \mathrm{NaH}_{2} \mathrm{PO}_{4}, 26 \mathrm{NaHCO}_{3}, 2 \mathrm{CaCl}_{2}$, and 10 glucose. After that, slices were transferred to normal ACSF at $32^{\circ} \mathrm{C}$ for $1 \mathrm{~h}$. ACSF was aerated continuously with a mixture of $95 \% \mathrm{O}_{2}$ and $5 \% \mathrm{CO}_{2}$. Slices were maintained at room temperature until used for recording.

Patch-clamp recording. Slices were transferred to a recording chamber where they were minimally submerged in high divalent cation ACSF (oxygenated in $95 \% \mathrm{O}_{2}$ and $5 \% \mathrm{CO}_{2}$ ) containing the following (in $\mathrm{mM}$ ): $121 \mathrm{NaCl}, 2.5 \mathrm{KCl}, 1.25 \mathrm{NaH}_{2} \mathrm{PO}_{4}, 4 \mathrm{CaCl}_{2}, 4 \mathrm{MgSO}_{4}, 26 \mathrm{NaHCO}_{3}$, and 10 glucose. High concentrations of divalent cations were used to suppress polysynaptic recurrent excitation (Shepherd et al., 2003; Jin et al., 2006), and $10 \mu \mathrm{M}$ 2-amino-5-phosphonovaleric acid (D-APV) was added to block NMDA receptor-dependent events and further reduce the possibility of polysynaptic responses (Jin et al., 2006; Kumar et al., 2007). Recordings were obtained at room temperature $\left(22-23^{\circ} \mathrm{C}\right)$ from cells identified by Nomarski optics with a $63 \times$ water-immersion lens and infrared video microscopy (Zeiss). Recordings were obtained with an Axopatch 700B amplifier and pClamp software, filtered at $2 \mathrm{kHz}$ for voltage clamp or $10 \mathrm{kHz}$ for current clamp, digitized at $20 \mathrm{kHz}$, and stored digitally. Series resistance was monitored continuously, and those cells in which this parameter changed by $>20 \%$ were rejected. Recording electrodes were pulled from borosilicate glass tubing $(1.5 \mathrm{~mm}$ outer diameter) and had a resistance of 3-5 $\mathrm{M} \Omega$ when filled with internal solution, which contained the following (in $\mathrm{mM}$ ): 100 potassium gluconate, 40 HEPES, 10 EGTA, $5 \mathrm{MgCl}_{2}$, $2 \mathrm{Na}_{2} \mathrm{ATP}, 0.5 \mathrm{NaGTP}$, and 20 biocytin. Osmolarity was adjusted to $300 \mathrm{mOsm}$ and $\mathrm{pH}$ to 7.3 with $1 \mathrm{M} \mathrm{KOH}$. Access resistance was $<20 \mathrm{M} \Omega$.

Photolysis of caged glutamate. An established glutamate uncaging protocol was used (Jin et al., 2006; Kumar et al., 2007; Brill and Huguenard, 2009). A frequency-tripled $\mathrm{Nd}: \mathrm{YVO}_{4}$ laser (series 3500 pulsed laser; 100 $\mathrm{kHz}$ repetition rate; DPSS Lasers) was interfaced with an upright micro- scope through its epifluorescence port via several mirrors and lenses. Movement of the laser beam was controlled with mirror galvanometers and triggered by scanning and data acquisition software (developed by one of the authors, J.R.H.), which also registered recorded soma position with respect to stimulation sites. Caged glutamate [200 $\mu \mathrm{M} ;(S)-\alpha-$ amino-2,3-dihydro-4-methoxy-7-nitro- $\delta$-oxo- $1 H$-indole-1-pentanoic acid; Tocris] was added to $20 \mathrm{ml}$ of recirculating high divalent cation ACSF at the beginning of each experiment. Focal photolysis of caged glutamate was accomplished by a $400 \mu \mathrm{s}, 170 \mathrm{~mW}$ UV light stimulus through a $5 \times$ objective to activate neurons. Half-width of the light beam was $\sim 50 \mu \mathrm{m}$. All neurons tested exhibited at least one action potential when photostimulated at the soma.

Data acquisition and analysis. Researchers were blind to experimental groups during data analysis but not during data acquisition. Intrinsic electrophysiological properties were measured. Input resistance was the slope of regression lines of plots of voltage responses to current steps less than or equal to $\pm 10 \mathrm{pA}$. Membrane time constants were calculated from single-exponential fits to voltage responses to hyperpolarizing currents. Action potential amplitude was measured from resting membrane potential to the peak.

Spontaneous and evoked EPSC data were evaluated using Mini Analysis (Synaptosoft). Threshold for event detection was set at three times root mean square noise level. EPSC recordings were obtained at the inhibitory reversal potential $(-70 \mathrm{mV})$ without pharmacologically blocking GABA receptor-mediated events. However, at the concentration used in the present study $(200 \mu \mathrm{M})$, the caged glutamate compound substantially but incompletely blocks $\mathrm{GABA}_{\mathrm{A}}$ receptors (Fino et al., 2009). Before collecting photostimulus-evoked responses, spontaneous EPSCs were recorded for at least $2 \mathrm{~min}$. Laser photostimuli randomly scanned the granule cell layer, hilus, and proximal CA3 pyramidal cell layer in a grid pattern with $60 \mu \mathrm{m}$ spacing and $1 \mathrm{~s}$ interstimulus intervals. Averages of $241 \pm 6$ and $247 \pm 7$ spots/slice were scanned for connectivity mapping of granule cells in control and epileptic rats, respectively.

Several parameters were evaluated to quantify synaptic connectivity. We identified spots that when stimulated evoked an EPSC in a recorded granule cell (see hot-spot criteria in Results). Percentage of hot spots was defined as the fraction of tested spots within a region that were identified as hot spots. Composite amplitude was defined as the sum of peak amplitudes of all synaptic events during the detection window (5-40 ms after the laser stimulus). Composite amplitude was used to construct connectivity maps. The number of EPSCs that occurred during detection windows was measured. Mean individual EPSC amplitude was calculated by dividing composite amplitude by number of EPSCs.

Connectivity maps were divided into four regions: granule cell layer ( $62 \pm 3$ spots in control; $73 \pm 4$ spots in epileptic), border (40 \pm 1 spots in control; $41 \pm 1$ spots in epileptic), hilus (110 \pm 5 spots in control; $104 \pm 5$ spots in epileptic), and CA3 pyramidal cell layer (26 \pm 1 spots in control; $28 \pm 1$ spots in epileptic) (see Fig. 1 B3). After electrophysiological data had been obtained and slices had been processed for neuronalspecific nuclear protein (NeuN)-labeling (see below), contours were drawn around the granule cell layer and proximal CA3 pyramidal cell layer. Neurons at the border of the granule cell layer and hilus include granule cells and hilar neurons. Therefore, spots touching the contour line between the granule cell layer and hilus were given special consideration and designated as "border" spots. Conversely "granule cell layer" spots were within the granule cell layer contour and did not touch the border with the hilus. The hilar region was limited by the border region and by straight lines drawn from the ends of the granule cell layer to the proximal end of the CA3 pyramidal cell layer. Only spots within stratum pyramidale and not other strata of CA3 were included as "CA3 pyramidal cell layer" spots.

Biocytin labeling. After electrophysiological recording, hippocampal slices were placed in $4 \%$ formaldehyde in $0.1 \mathrm{~m}$ phosphate buffer (PB), $\mathrm{pH} 7.4$, at $4^{\circ} \mathrm{C}$ for at least $24 \mathrm{~h}$. After fixation, slices containing biocytinlabeled cells were stored in $30 \%$ ethylene glycol and $25 \%$ glycerol in 50 $\mathrm{mm} \mathrm{PB}$ at $-20^{\circ} \mathrm{C}$ until they were processed using a whole-mount protocol with counterstaining by NeuN immunocytochemistry. Slices were rinsed in $0.5 \%$ Triton X-100 and $0.1 \mathrm{M}$ glycine in $0.1 \mathrm{M} \mathrm{PB}$, and then placed in a blocking solution containing $0.5 \%$ Triton X-100, $2 \%$ goat 
serum (Vector), and 2\% bovine serum albumin in $0.1 \mathrm{M} \mathrm{PB}$ for $4 \mathrm{~h}$. Slices were incubated in mouse anti-NeuN serum (1:100; MAB377; Millipore Bioscience Research Reagents) in blocking solution overnight. Slices were then rinsed in $0.5 \%$ Triton X-100 and $0.1 \mathrm{~m}$ glycine in $0.1 \mathrm{M} \mathrm{PB}$ and incubated with Alexa 594 streptavidin $(5 \mu \mathrm{g} / \mathrm{ml})$ and Alexa 488 goat anti-mouse ( $10 \mu \mathrm{g} / \mathrm{ml}$; Invitrogen) in blocking solution overnight. Slices were rinsed in $0.5 \%$ Triton X-100 and $0.1 \mathrm{M}$ glycine in $0.1 \mathrm{M} \mathrm{PB}$, mounted on slides, coverslipped with Vectashield (Vector), and imaged with a confocal microscope (Zeiss).

Neuron density analysis. After immunoprocessing and collecting images of biocytin-labeled recorded neurons, slices were cryoprotected in $30 \%$ sucrose in $0.1 \mathrm{M} \mathrm{PB}$ and sectioned with a microtome set at $40 \mu \mathrm{m}$. A section from each slice was mounted on a glass slide and coverslipped in Vectashield. NeuN immunoreactivity was imaged throughout the section thickness with a $10 \times$ objective on a confocal microscope. Neurolucida (MBF Bioscience) was used to draw a contour around the hilus (as defined above), and the area was recorded. The number of hilar NeuNpositive profiles was counted, and density was calculated by dividing by hilar area. Nissl staining was superior to NeuN immunoreactivity for visualizing individual neuronal somata in cell layers. A section from each slice was stained with $0.25 \%$ thionin. Using Neurolucida and a $10 \times$ objective, a contour was drawn around the CA3 pyramidal cell layer from the proximal tip to a level determined by a straight line drawn across the tips of the granule cell layer, and the area was recorded. Using a $100 \times$ objective, all neuron profiles within the proximal CA3 pyramidal cell contour were counted. Proximal CA3 pyramidal cell density was calculated by dividing the number of neuron profiles by area. To estimate granule cell profile density, a contour was drawn around the granule cell layer. Stereo Investigator (MBF Bioscience) was used to systematically sample within the granule cell layer (counting frame, $20 \times 20 \mu \mathrm{m}$; counting grid, $200 \times 200 \mu \mathrm{m}$ ). Using a $100 \times$ objective, granule cell soma profiles were counted if they fell at least partially within the counting frame but did not touch upper or left borders. Granule cell profile density was measured by dividing number of counted profiles by sampled area.

All chemicals were from Sigma-Aldrich unless specified otherwise. Statistical values are presented as mean \pm SEM. The level of $p<0.05$ was considered statistically significant.

\section{Results \\ Distinguishing direct versus synaptic responses to glutamate photo-uncaging}

Laser-scanning photostimulation is a powerful approach for efficiently evaluating neuronal circuits, but it is not necessarily a direct measure of monosynaptic connectivity. Therefore, several experiments were conducted to establish validity before comparing connectivity of control and epileptic animals. Direct versus synaptic responses to glutamate uncaging were identified as described previously (Kumar et al., 2007). In voltage-clamp mode, direct responses evoked at sites close to recorded granule cell somata or proximal dendrites consistently had short onset latencies $(<5 \mathrm{~ms})$ and persisted after bath application of tetrodotoxin ( $1 \mu \mathrm{M} ; n=5$; data not shown). In current-clamp recordings, an action potential could be triggered shortly after the onset of a direct response. An EPSC would be generated in the synaptic targets of the directly activated neuron after a delay for action potential propagation and synaptic transmission. Therefore, responses with onset latencies $>5 \mathrm{~ms}$ after photostimulation were considered to be synaptic. A relatively short detection window (5-40 ms, $35 \mathrm{~ms}$ duration) reduced the probability of confounding effects through polysynaptic activation.

\section{Minimizing contamination by spontaneous EPSCs}

Spontaneous EPSC frequency increases in granule cells in epileptic pilocarpine-treated rats (Simmons et al., 1997; Wuarin and Dudek, 2001). Spontaneous events that occur within the detection window could be mistaken as evoked EPSCs. To reduce that possibility, slices in the present study were bathed in the presence of D-APV and high concentrations of divalent cations. Under those conditions, frequencies of sEPSCs were similar in granule cells from control $(4.1 \pm 0.6 \mathrm{~Hz} ; n=33)$ and epileptic rats $(4.2 \pm$ $0.4 \mathrm{~Hz} ; n=38)$, suggesting any effect of spontaneous events would be equal in both groups. To further decrease contamination of spontaneous events, photostimulation scanning was completed three times for each granule cell, and the three resulting maps were merged into an average map by a "two successes" filtering criterion (Fig. 1). That is, only sites associated with EPSCs in their detection windows during at least two of three trials were considered to be sites of presynaptic neurons ("hot spots"). At those sites, responses of all nonfailure trials were averaged. Together, the "two successes" criterion and similar sEPSC frequencies in control and epileptic rats reduced possible confounding effects of sEPSCs and polysynaptic activation on connectivity maps.

\section{Testing reliability of sites identified as hot spots}

To test the reliability of this method for locating presynaptic neurons, individual hot spots were stimulated repetitively at $30 \mathrm{~s}$ intervals for 7-14 trials (Fig. 2). Several parameters were measured to evaluate consistency of evoked EPSCs. Onset latency was measured as the interval between the onset of laser stimulation and the onset of the first EPSC in the detection window. Latency jitter was calculated as the SD of the Gaussian distribution of onset latencies (bin size, $0.2 \mathrm{~ms}$ ). Success rate was measured as the number of trials evoking at least one EPSC in detection windows divided by the total number of trials. All tested hot spots had short average onset latency ( $8-14 \mathrm{~ms})$, low average latency jitter $(0.49-0.55 \mathrm{~ms})$, and high average success rate (>75\%) (Fig. 2 B). There was no correlation between onset latency and latency jitter for evoked EPSCs $\left(R^{2}=0.02-0.08\right)$. Such a correlation would be expected if evoked EPSCs contained both monosynaptic and longer latency polysynaptic responses with increased jitter (Larimer and Strowbridge, 2008).

\section{Measuring intrinsic physiology and direct responses to glutamate photo-uncaging}

Intrinsic excitability of principle neurons may increase in epilepsy (Prince and Tseng, 1993; Jin et al., 2005). Changes in intrinsic physiology could enhance responses of granule cells to synaptic inputs. To test this possibility, intrinsic physiology of granule cells was measured and compared in control and epileptic rats. There were no significant differences in resting membrane potential, input resistance, membrane time constant, action potential amplitude, or action potential frequency in response to a $200 \mathrm{pA}, 500 \mathrm{~ms}$ depolarizing current step (Table 1).

Glutamate receptor density of principal neurons can increase in epilepsy (Mody and Heinemann, 1987; Babb et al., 1996; Mathern et al., 1998), which could enhance direct responses to uncaged glutamate, resulting in more action potential firing of neurons in epileptic rats compared with controls. Hyperexcitability could make hot spots more likely to be detected with equivalent photostimulation in epileptic animals, which would be a confounding factor when evaluating connectivity. To test this possibility, neurons in control and epileptic rats were evaluated to determine whether their direct responses to glutamate uncaging were similar under our stimulation and recording conditions (Fig. 3). Whole-cell or cell-attached current-clamp recording was used to obtain responses of granule cells $(n=14$ in control; $n=20$ in epileptic), mossy cells ( $n=11$ in control; $n=$ 9 in epileptic), CA3 pyramidal cells $(n=11$ in control; $n=12$ in 


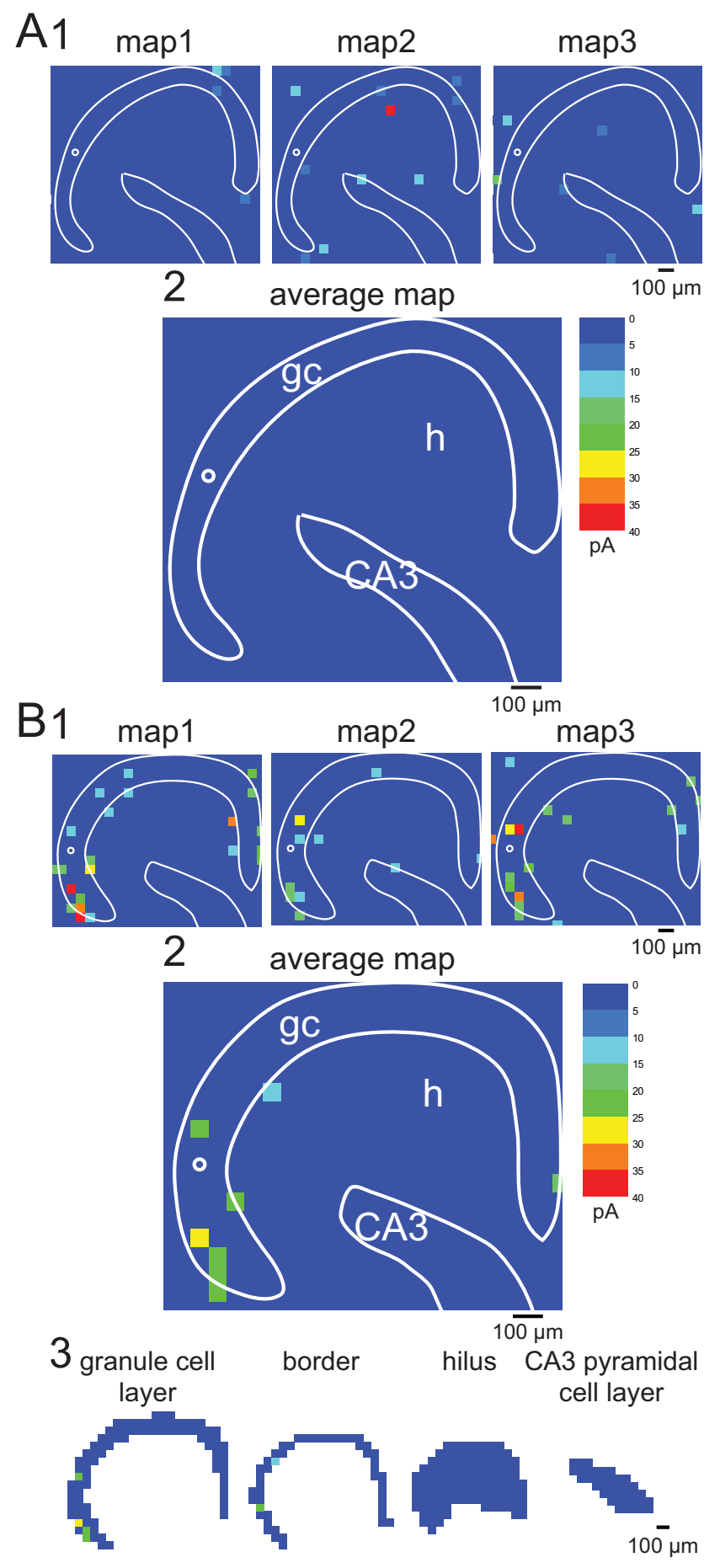

Figure 1. A "two successes" filtering criterion reduced contamination of connectivity maps by spontaneous events. For a recorded granule cell (indicated by white open circle) in a slice from a control $(\boldsymbol{A})$ and epileptic rat $(\boldsymbol{B})$, photostimulation scanning was completed three times, and the resulting maps $(\boldsymbol{A} \mathbf{1}, \boldsymbol{B} 1)$ merged into a map of averaged successes $(\boldsymbol{A} 2, \boldsymbol{B} 2)$ by only including spots in which events were detected in at least two of the three trials ("hot spots"). gc, Granule cell layer; $h$, hilus; CA3, CA3 pyramidal cell layer. Using this criterion, the granule cell in the control slice had no hot spots, and the granule cell in the epileptic slice had eight hot spots. B3, To evaluate contributions from different areas, scanned areas were divided into four regions: granule cell layer, border (between the granule cell layer and hilus), hilus, and CA3 pyramidal cell layer.

epileptic), and hilar ectopic granule cells ( $n=7$ in epileptic). Maps $(540 \times 540 \mu \mathrm{m}$, centered on recorded neurons) were scanned with $60 \mu \mathrm{m}$ spacing, $400 \mu$ s stimulus durations, and 170 $\mathrm{mW}$ stimulus intensity in normal ACSF with $200 \mu \mathrm{M}$ caged glu- tamate. All neurons responded with at least one short-latency action potential when photostimuli were located close to the soma or proximal dendrites (latency to peak, $6.2 \pm 0.2 \mathrm{~ms} ; n=$ 488 action potentials). The number of action potential-evoking spots per cell was smaller for normotopic granule cells and hilar ectopic granule cells compared with those of mossy cells and CA3 pyramidal cells (see Fig. $3 B$ ), which is consistent with size differences of the neuron types. However, for each cell type, there was no significant difference between control and epileptic rats in the number of action potential-evoking spots per cell or number of action potentials per action potential-evoking spot.

Maps constructed to compare direct responses to glutamate uncaging also were used to test whether or not polysynaptic activation occurred. Each map tested 81 spots in a $540 \times 540 \mu \mathrm{m}$ area. In a subset of cells (controls: eight mossy cells and six CA3 pyramidal cells; epileptics: three granule cells, five mossy cells, five CA3 pyramidal cells, and six hilar ectopic granule cells), maps were expanded to include the entire granule cell layer, hilus, and proximal CA3 region ( $425 \pm 9$ stimulation sites per map). If polysynaptic activation occurred, postsynaptic target neurons should receive EPSPs that trigger an action potential. Despite the large number of sites tested $(>18,000)$, photostimulation only evoked action potentials by direct activation at sites close to the soma or proximal dendrites, never at more distant locations. These findings suggest that, under our stimulation and recording conditions, directly activated neurons failed to bring their postsynaptic targets to threshold for firing an action potential. Therefore, recorded EPSCs were rarely if ever generated by polysynaptic activation and instead were likely to be monosynaptic.

\section{Reduced neuron density in epileptic animals}

Neuron loss occurs in the dentate gyrus of epileptic pilocarpinetreated rats (Mello et al., 1993; Kobayashi and Buckmaster, 2003). All other things being equal, slices with lower neuron density would be expected to display fewer hot spots. Densities of neuronal profiles were measured in the proximal CA3 pyramidal cell layer, hilus, and granule cell layer (Fig. 4). All regions demonstrated reduced neuron density in epileptic rats. The most severe loss was in the CA3 pyramidal cell layer where profile density decreased almost by one-half $(0.0041 \pm 0.0003$ vs $0.0022 \pm$ $\left.0.0001 / \mu \mathrm{m}^{2} ; p<0.001\right)$. Neuron profile density in the hilus of epileptic rats, which is likely a balance of neuron loss during status epilepticus and subsequent addition of newly generated ectopic granule cells, was reduced to $70 \%$ of the control value $\left(0.00082 \pm 0.00006\right.$ vs $\left.0.00057 \pm 0.00005 / \mu \mathrm{m}^{2} ; p<0.005\right)$. The granule cell layer demonstrated moderate but significant reductions in profile densities in epileptic rats $(0.0194 \pm 0.0010 \mathrm{vs}$ $\left.0.0150 \pm 0.0007 / \mu^{2} ; p<0.001\right)$. Therefore, based on neuron density alone, one would expect reduced connectivity in epileptic animals compared with controls.

\section{Increased recurrent excitation of granule cells in epileptic animals}

Experiments described above established the validity of the glutamate photo-uncaging approach for comparing connectivity maps of normotopic granule cells in slices from control and epileptic rats. Furthermore, neuron profile density measurements suggested epileptic rats would have reduced connectivity unless synaptic reorganization had occurred. To evaluate recurrent excitatory circuits of granule cells, whole-cell voltage-clamp recordings were obtained from 33 and 38 granule cells in slices from control and epileptic rats, respectively. Laser stimuli (400 $\mu \mathrm{s}$ stimulus duration, $170 \mathrm{~mW}$ stimulus intensity, $200 \mu \mathrm{M}$ caged- 


\section{A granule cell layer}
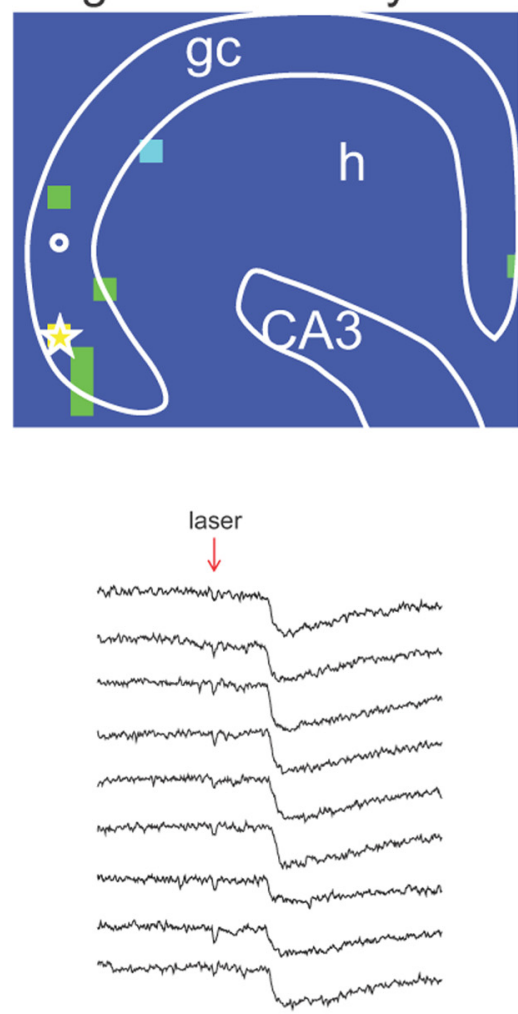

B

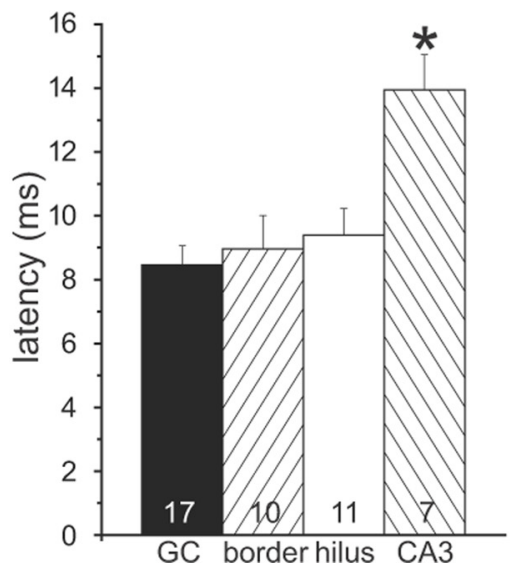

hilus
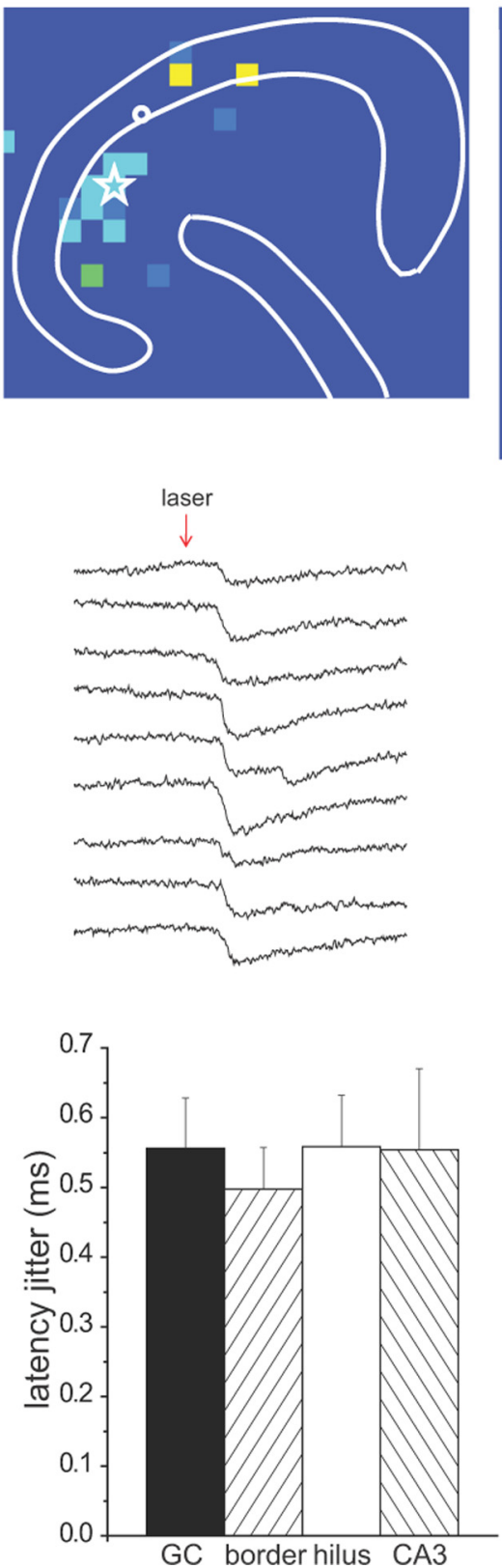

CA3
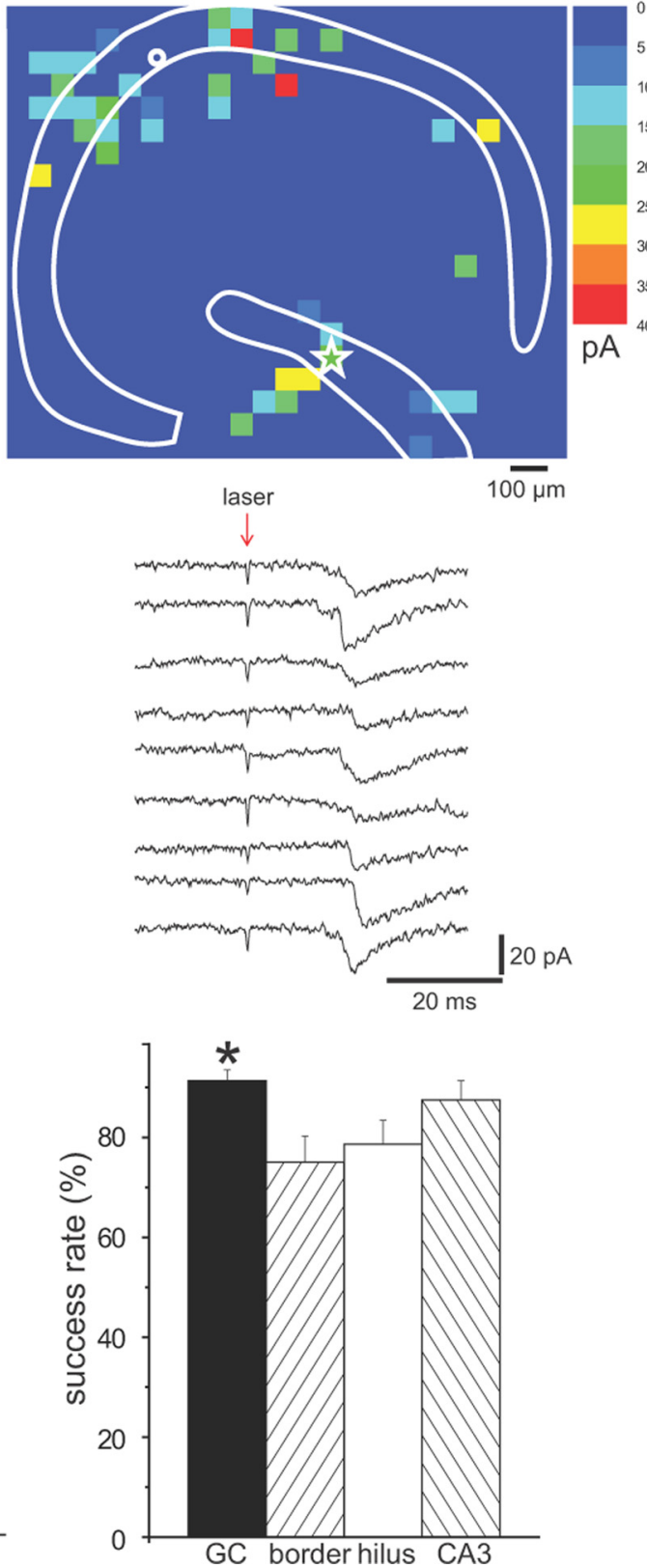

Figure 2. Laser-scanning photo-uncaging of glutamate evoked likely monosynaptic responses in granule cells. $A$, EPSCs evoked by photostimulating the same hot spot (white star) in the granule cell layer (left), hilus (middle), and CA3 pyramidal cell layer (right) in slices from epileptic rats. Connectivity maps are shown in the top panels; consecutive EPSCs are shown in the bottom panels. Site of recorded granule cells is indicated by white circles. $\boldsymbol{B}$, Group data for hot spots stimulated consecutively in the granule cell layer (GC), border region, hilus, or CA3 pyramidal cell layer. Average latency from laser stimulation to onset of EPSC (left graph) was relatively short for all regions. Hot spots in CA3 had longer latencies than other regions ( $\left.{ }^{*} p<0.05\right)$. Average latency jitter (middle graph) was small and similar for hot spots in all regions. Average success rate for evoking an EPSC (right graph) was high for all regions and highest in the granule cell layer. There were no significant differences between slices from control versus epileptic rats, so data were combined. The number of hot spots tested is indicated in bars of the latency graph. Graphs indicate mean \pm SEM.

Table 1. Intrinsic electrophysiological properties of normotopic granule cells in control and epileptic rats

\begin{tabular}{lcc}
\hline & Control & Epileptic \\
\hline$n$ (cells) & 32 & 37 \\
Resting membrane potential $(\mathrm{mV})$ & $-71 \pm 1$ & $-71 \pm 1$ \\
Input resistance $(\mathrm{M} \Omega$ ) & $310 \pm 19$ & $272 \pm 15$ \\
Membrane time constant $(\mathrm{ms})$ & $22 \pm 2$ & $25 \pm 1$ \\
Action potential threshold $(\mathrm{mV})$ & $-32 \pm 1$ & $-34 \pm 1$ \\
Action potential amplitude $(\mathrm{mV})$ & $125 \pm 2$ & $125 \pm 2$ \\
Action potential frequency $(\mathrm{Hz}$ at 200 pA) & $18 \pm 2$ & $19 \pm 1$ \\
\hline
\end{tabular}

Values indicate mean \pm SEM. There were no statistically significant differences. glutamate in ACSF) were applied to the granule cell layer, hilus, and proximal CA3 pyramidal cell layer in a grid pattern with 60 $\mu \mathrm{m}$ spacing. Maps were constructed of recurrent excitatory connectivity based on composite amplitudes of evoked EPSCs at each spot (Fig. 5). Composite amplitude is the summed amplitude of EPSCs that occur during the detection window (5-40 ms after laser stimulation). Most maps of control rat slices contained relatively few if any hot spots. Some maps of epileptic rat slices were similar to controls, but most contained more hot spots in the granule cell layer, hilus, and/or proximal CA3 pyramidal cell layer. Maps of slices from epileptic rats were more likely than 

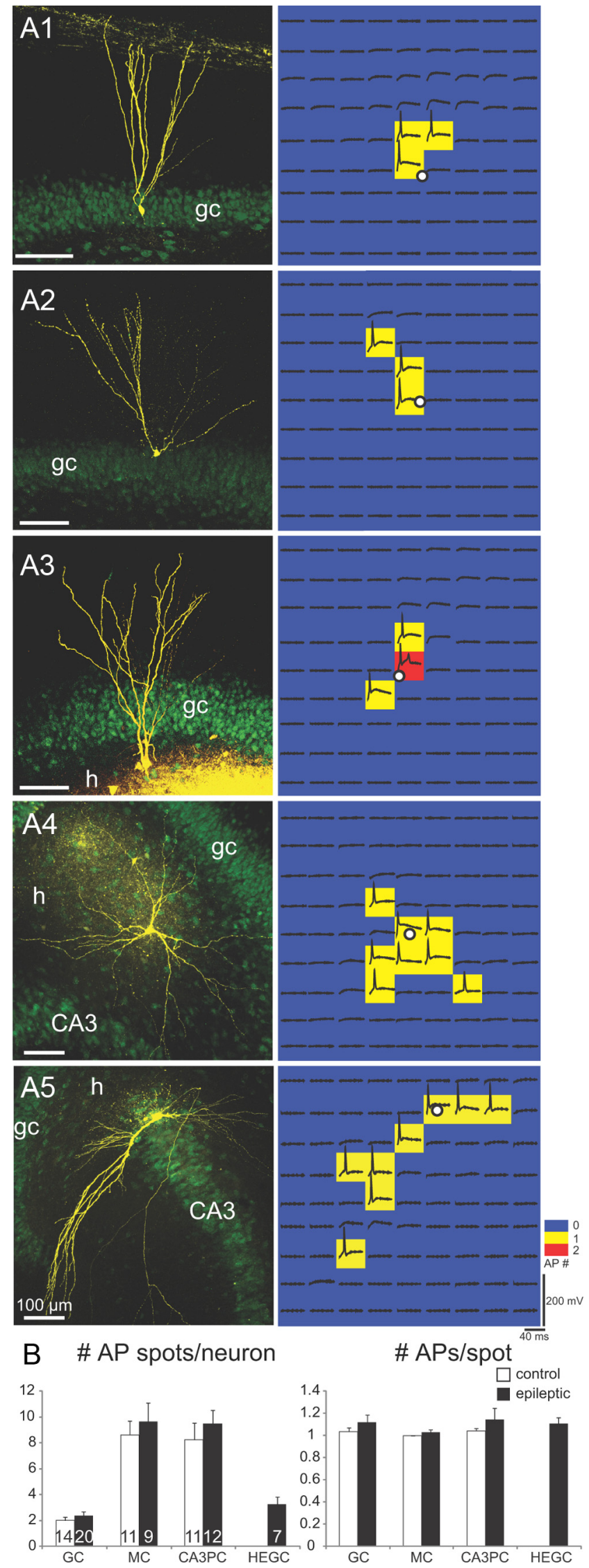

Figure 3. No differences between control and epileptic rats in direct responses to glutamate photo-uncaging. Laser stimulation at sites near somata and proximal dendrites of recorded neurons evoked action potentials in a normotopic granule cell in a slice from a control rat (A1), normotopic granule cell in an epileptic rat (A2), hilar ectopic granule cell in an epileptic rat $(\boldsymbol{A 3})$, mossy cell those of controls to have at least one hot spot in the granule cell layer [33 of 38 $(87 \%)$ vs 11 of $\left.33(33 \%) ; p<0.005, \chi^{2}\right]$, border [28 of $38(74 \%)$ vs 12 of $33(36 \%)$; $p<0.005$ ], and hilus [ 27 of $38(71 \%)$ vs 12 of $33(36 \%) ; p<0.005]$. A larger proportion of tested sites in the CA3 pyramidal cell layer were hot spots in epileptic rats compared with controls [10 of 38 (26\%) vs 5 of $33(15 \%)$ ], but the difference was not statistically significant.

To quantify and compare connectivity between control and epileptic groups, hot-spot ratios were calculated (Fig. $6 A$ ). Hot-spot ratios in the granule cell layer were higher in epileptic rats compared with controls $(6.7 \pm 1.2$ vs $1.4 \pm 0.5 \%$; $p<0.0005)$, suggesting more recurrent excitatory inputs from normotopic granule cells. Hot-spot ratios of the hilus $(6.0 \pm 1.6 \%$ in epileptic vs $1.9 \pm 0.7 \%$ in control; $p<0.05)$ and proximal CA3 pyramidal cell layer $(4.2 \pm 1.3 \%$ in epileptic vs $0.6 \pm 0.3 \%$ in control; $p<0.05$ ) also were higher in epileptic rats. For all regions combined, hot-spot ratios were four times higher in epileptic rats $(7.6 \pm 1.8 \%$ of stimulation sites) than in controls $(1.9 \pm 0.5 \%$; $p<0.01$ ) (Fig. $6 B)$. The border region showed the smallest increase (2.7 times controls), and the CA3 pyramidal cell layer increased most (6.6 times controls). Therefore, contrary to expectations based on reduced neuron density, these findings suggest that, compared with controls, epileptic rats have more neurons in the hilus and proximal CA3 pyramidal cell layer that synapse with and excite granule cells.

Higher hot-spot ratios in slices from epileptic animals suggest granule cells, hilar neurons, and CA3 pyramidal cells sprouted axons and formed new synapses with normotopic granule cells. If so, one might expect presynaptic neurons to have longer axon trajectories in epileptic animals. To begin testing that possibility, distances from hot spots to recorded granule

$\longleftarrow$

in a control rat (A4), and CA3 pyramidal cell in a control rat (A5). Biocytin-labeled recorded neurons (yellow) and NeuN immunoreactivity (green) are shown in the left panels. Corresponding maps of membrane potential responses to glutamate photo-uncaging are shown in the right panels. $\boldsymbol{B}$, Group data revealed no significant differences between control and epileptic rats in the number of action potential-evoking spots per map (left graph) or number of action potentials evoked per spot (right graph) for normotopic granule cells (GC), mossy cells (MC), and CA3 pyramidal cells (CA3PC). Hilar ectopic granule cells (HEGC) were found only in slices from epileptic rats. The number of cells is indicated in the bars of left graph. Values represent mean $\pm S E M$. 

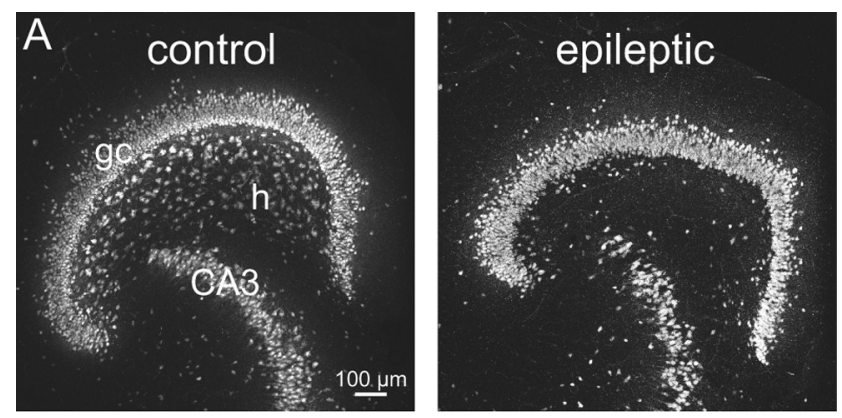

B

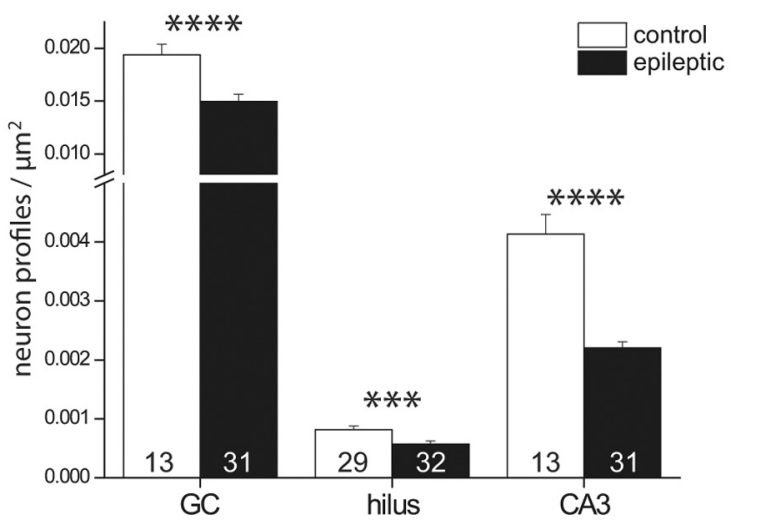

Figure 4. Neuron profile density was reduced in epileptic rats. $\boldsymbol{A}$, NeuN-immunostained section of a slice from a control (left) and epileptic rat (right). gc, Granule cell layer; $h$, hilus; CA3, CA3 pyramidal cell layer. $\boldsymbol{B}$, Group data reveal reduced neuron profile densities in epileptic rats. The number of slices is indicated in bars. Graphed values represent mean \pm SEM. ${ }^{* * *} p<$ 0.005 ; $^{* * *} p<0.001$.

cells were measured. Mean distance to recorded granule cells was farther for hot spots in the granule cell layer $(352 \pm 20$ vs $248 \pm$ $39 \mu \mathrm{m} ; p<0.05)$, hilus ( $487 \pm 18$ vs $310 \pm 28 \mu \mathrm{m} ; p<0.005)$, and CA3 pyramidal cell layer $(823 \pm 28$ vs $574 \pm 36 \mu \mathrm{m} ; p<$ 0.005 ) in epileptic rats compared with controls, respectively (Fig. $6 C)$.

To measure strength of excitatory synaptic input to granule cells evoked by glutamate uncaging, composite EPSC amplitude within detection windows was measured. Average composite amplitudes per hot spot of epileptic rats were larger than those of controls for responses evoked by stimulating in the granule cell layer, CA3 pyramidal cell layer, and border regions, but not in the hilus (Fig. 6D). Composite amplitude is determined by the number of EPSCs during the detection window and the amplitudes of individual EPSCs. Average numbers of EPSCs evoked per hot spot always were close to 1 (Fig. $6 E$ ). Numbers of EPSCs tended to be larger in all regions in epileptic rats compared with controls and reached statistical significance in the granule cell layer and hilus. Increased EPSC number could be attributable to more action potentials discharged per neuron or more neurons activated per site. In control and epileptic rats, granule cells and mossy cells each had similar numbers of action potentials evoked by direct stimulation (Fig. 3B). Therefore, increased EPSC numbers probably reflect more presynaptic neurons activated per hot spot and more recurrent excitatory connectivity in epileptic rats. Mean amplitudes of individual EPSCs were calculated by dividing composite amplitudes by the number of EPSCs during detection windows. Mean amplitudes of individual EPSCs were larger in epileptic animals compared with controls for hot spots in the granule cell layer, CA3 pyramidal cell layer, and border regions, but not in the hilus (Fig. 6F). These findings suggest recurrent excitatory synaptic circuits to granule cells from CA3 pyramidal cells and from other granule cells are not only more frequent but also stronger in epileptic animals compared with controls, which is consistent with larger excitatory synapses found on proximal dendrites of granule cells in epileptic animals (Thind et al., 2010).

Excitatory synaptic input to hilar ectopic granule cells

Hilar ectopic granule cells normally are rare but develop after epileptogenic injuries (Parent et al., 1997; Scharfman et al., 2000), and occur in patients with temporal lobe epilepsy (Houser et al., 1990; Parent et al., 2006). They have been proposed to contribute to epileptogenesis in part because their soma and much of their dendrites are located in the hilus among granule cell axons, suggesting they receive abnormally high levels of excitatory synaptic input from normotopic granule cells (Pierce et al., 2005). Their hilar position also might increase their probability of receiving synaptic input from other excitatory neurons in the area, including proximal CA3 pyramidal cells. The frequency of mEPSCs is higher in ectopic compared with normotopic granule cells in epileptic pilocarpine-treated rats (Zhan et al., 2010), which is consistent with more excitatory synapses and/or higher probability of glutamate release. To further evaluate excitatory synaptic input to hilar ectopic granule cells, small, round hilar neurons were targeted for recording $(n=18)$. Biocytin labeling confirmed that their morphological characteristics matched those of hilar ectopic granule cells (Cameron et al., 2011; Pierce et al., 2011), which included a small soma positioned in the hilus. All biocytinlabeled ectopic granule cells in the present study had a spiny dendrite that extended through the granule cell layer and into the molecular layer (Fig. 7). Mossy fiber boutons were evident on ectopic granule cell axons that extended in the hilus with a primary branch projecting toward, and in some cases into, stratum lucidum of CA3 (Fig. 7D).

To evaluate synaptic inputs to hilar ectopic granule cells, laserscanning glutamate uncaging was used as described above to construct excitatory connectivity maps (Fig. 8). Results of hilar ectopic granule cells were largely similar to those of normotopic granule cells in epileptic rats (Fig. 6). However, there were some differences. For example, as expected because of their position in the hilus instead of the granule cell layer, distances from hilar and CA3 hot spots were shorter for ectopic granule cells compared with normotopic granule cells in epileptic rats (Fig. 6C). Unlike normotopic granule cells in epileptic rats, hilar stimulation did not evoke a higher hot-spot ratio in hilar ectopic granule cells compared with granule cells in controls. And stimulation sites in the granule cell layer tended to evoke more EPSCs in ectopic granule cells compared with normotopic granule cells in epileptic animals (Fig. 6E), but individual EPSC amplitudes were not different (Fig. 6F).

\section{Discussion}

Glutamate photo-uncaging in the hilus and CA3 pyramidal cell layer rarely synaptically excited granule cells in control rats. The principal finding of this study was that, despite reduced neuron densities in epileptic rats, photostimulation evoked increased recurrent excitatory responses. These results suggest that, in addition to mossy fiber sprouting, other sources of positive feedback to granule cells develop from hilar and CA3 neurons, which might be epileptogenic.

\section{CA3-to-granule cell circuit}

Normally, some CA3 pyramidal cells make retrograde axon projections into the hilus (Ishizuka et al., 1990). Within the hilus, 
A
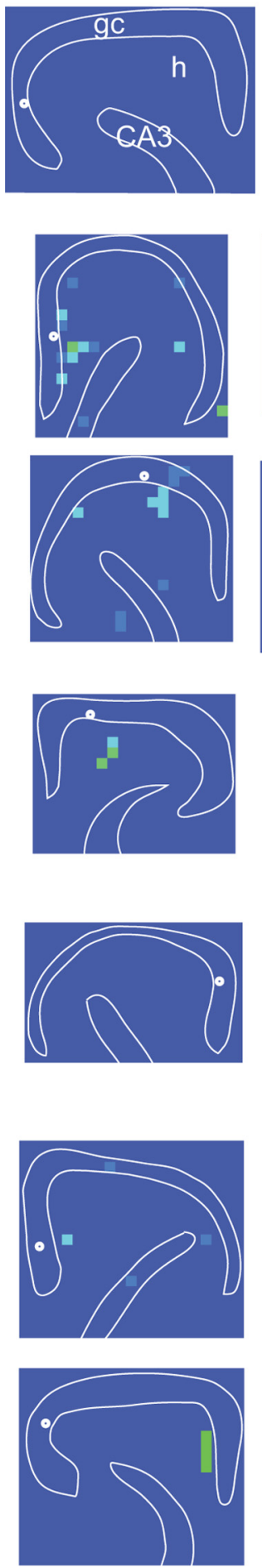

B
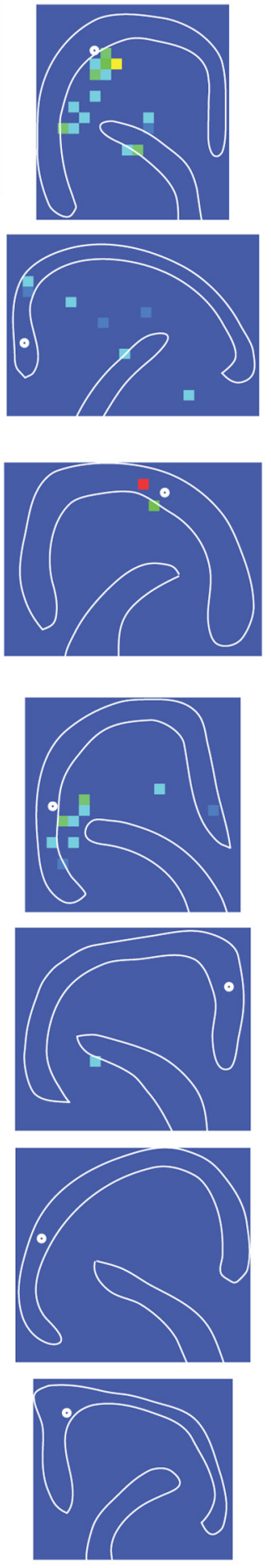
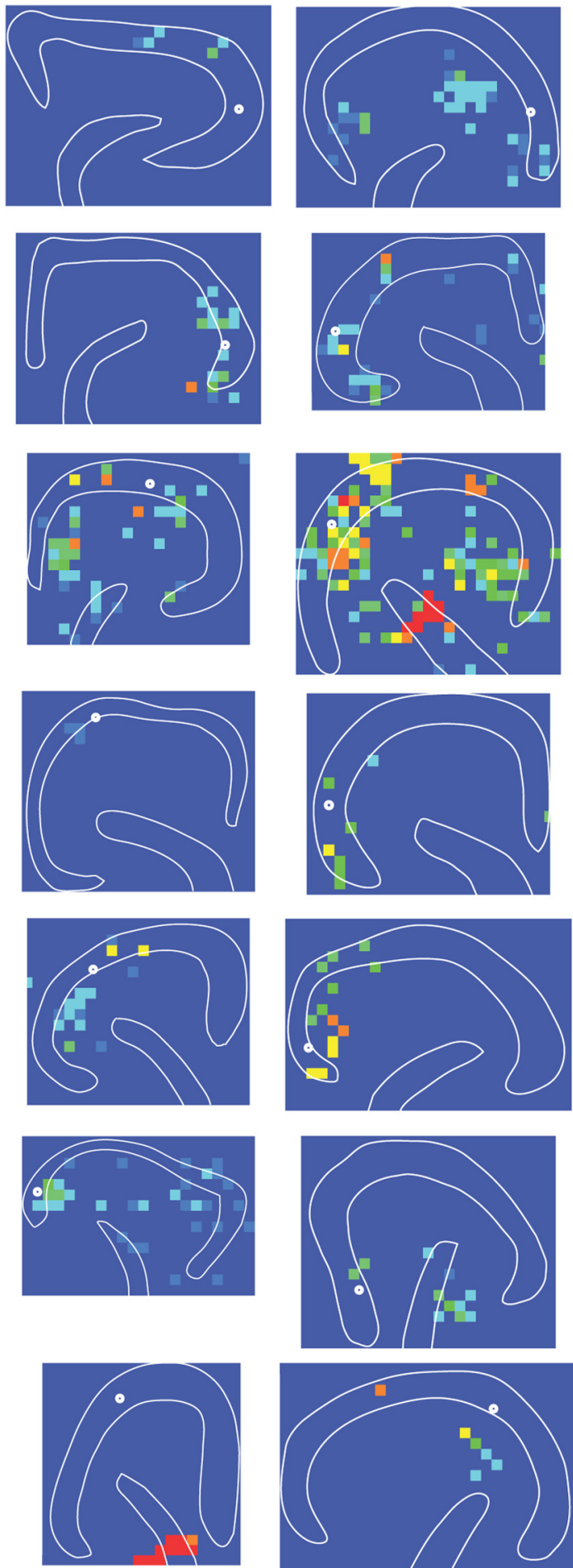

\section{epileptic}
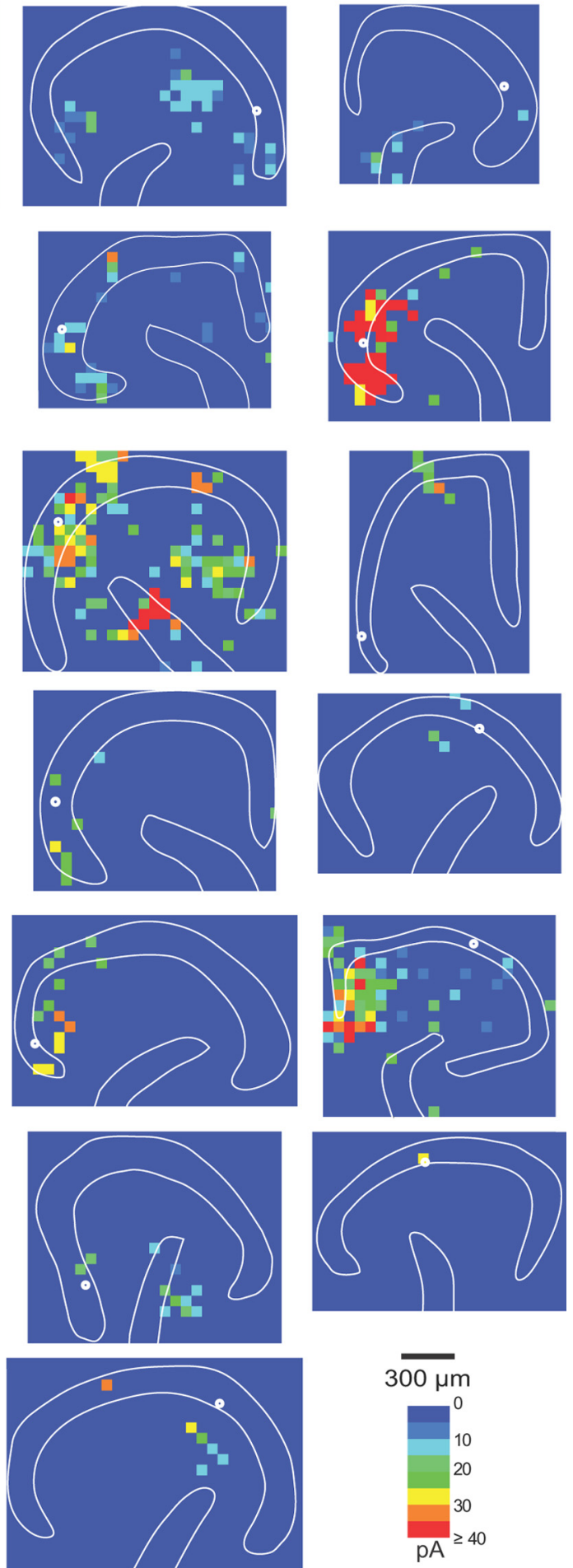

Figure 5. Connectivity maps based on composite amplitudes of glutamate photo-uncaging-evoked EPSCs in slices from control $(\boldsymbol{A})$ and epileptic rats (B). Sites of recorded normotopic granule cells are indicated by white circles. gc, Granule cell layer; h, hilus; CA3, CA3 pyramidal cell layer. Recordings were obtained from 71 granule cells (33 in controls; 38 in epileptics) in 65 slices (31 in controls; 34 in epileptics) from 43 rats (18 in controls; 25 in epileptics).

pyramidal cell axons synapse with mossy cells (Scharfman, 1994), which raises the possibility that photostimulated pyramidal cells excited granule cells indirectly through mossy cells in the present study. This seems unlikely. Photo-uncaging in CA3 evoked responses in granule cells with low failure rates and little jitter in onset latencies, which is more consistent with monosynaptic than disynaptic transmission. Furthermore, photostimulating CA3 never evoked an action potential in recorded mossy cells. CA3 
A hotspot ratio

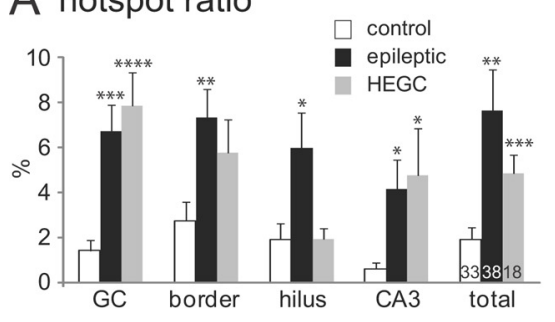

C hotspot distance

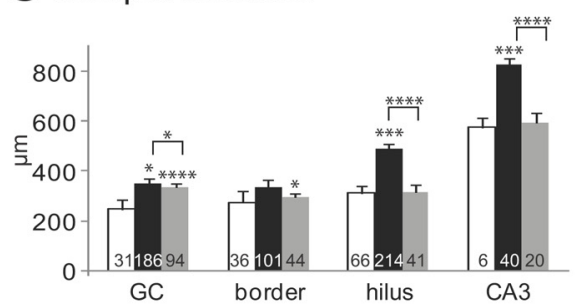

$E$ \# of evoked EPSCs

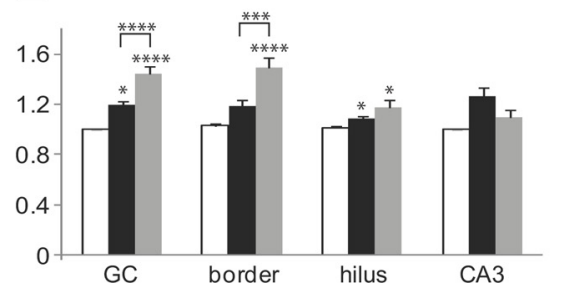

B epileptic / control ratio

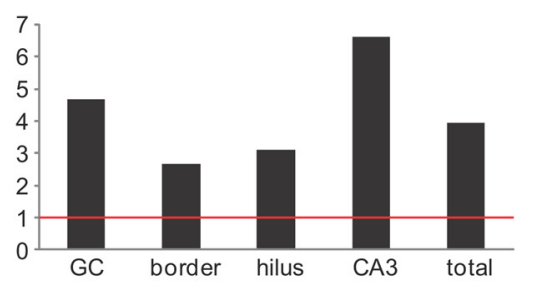

D composite EPSC amplitude

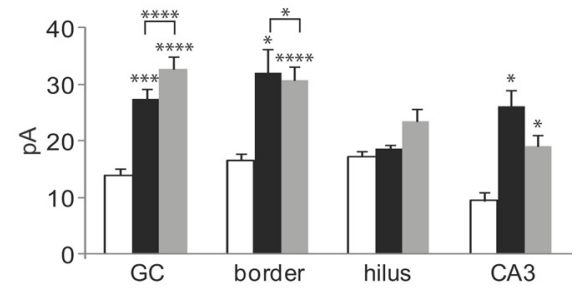

$\mathrm{F}$ individual EPSC amplitude

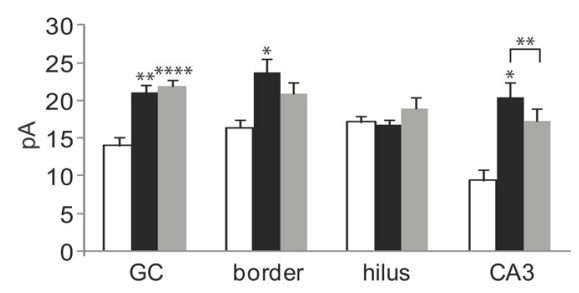

vulgaris-leucoagglutinin was injected into CA3 (Siddiqui and Joseph, 2005). Together, these findings suggest that, after epileptogenic injuries, surviving CA3 pyramidal cells sprout axons into the molecular layer that synapse with dendrites of normotopic granule cells.

\section{Hilar neuron-to-granule cell circuits}

Hilar photostimulation evoked EPSCs in granule cells in controls and even more frequently in epileptic animals. Previous glutamate uncaging and microdrop studies reported no excitatory inputs from the hilus (Wuarin et al., 1996; Molnár and Nadler, 1999). In the present study, success rate for evoking an EPSC by photostimulation appeared to be high $(>75 \%$; Fig. 2B), which facilitated detection of functional connectivity, and the entire hilus was scanned with $60 \times 60 \mu \mathrm{m}$ resolution. Other potential contributing factors include animal age, which can affect hilar neuron survival in slices, and duration and severity of status epilepticus, which affects hilar neuron loss.

Results of the present study do not distinguish whether increased hot-spot probability in the hilus of epileptic rats is attributable to mossy cells, ectopic granule cells, or both. Normally, because of their preferentially distant axon projections, mossy cell-to-granule cell circuits are mostly but not completely amputated in hippocampal slices (Buckmaster et al., 1992; Scharfman, 1995). Hilar hot spots in slices from control rats probably are attributable to mossy cells. In patients with temporal lobe epilepsy (Blümcke et al., 2000; Seress et al., 2009) and in animal models (Buckmaster and Jongen-Rêlo, 1999; Jiao and Nadler,

pyramidal cell axons might synapse with granule cell basal dendrites that develop in patients (Franck et al., 1995; von Campe et al., 1997) and animal models of temporal lobe epilepsy (Spigelman et al., 1998), including pilocarpine-treated rats (Thind et al., 2008). However, 39 of 71 recorded granule cells were biocytin labeled sufficiently to determine whether they had a basal dendrite and none did. CA3 pyramidal cells normally synapse with dentate interneurons (Kneisler and Dingledine, 1995). CA3 input to at least one type of dentate interneuron (GFP-positive somatostatin hilar neurons in GIN mice) increases in epileptic pilocarpine-treated mice (Hunt et al., 2011), which supports the hypothesis of epilepsy-related axon sprouting by CA3 pyramidal cells.

In control rats, CA3 pyramidal cells occasionally project axons into the molecular layer of the dentate gyrus (Li et al., 1994). This occurs most frequently in the temporal hippocampus, from which slices were obtained in the present study, and is consistent with the low but nonzero hot-spot ratios in CA3 of control animals. In epileptic rats, despite substantially reduced neuron density, the average hot-spot ratio in CA3 increased over six times that of controls, which is consistent with many more fibers projecting into the dentate gyrus molecular layer after Phaseolus
2007), many but usually not all mossy cells die. Reduced hilar neuron profile density in the present study is consistent. Surviving mossy cells might sprout axons and form new synapses with nearby granule cells, which could account for increased hot-spot probabilities in epileptic animals. Another major hilar cell type, somatostatin interneurons, sprout axons and form new synapses with granule cells in epileptic pilocarpine-treated mice (Zhang et al., 2009). Mossy cells have the capacity to sprout axons and form new synapses even in adult animals (Benowitz and Routtenberg, 1997; Namgung et al., 1997; Del Turco et al., 2003; Prang et al., 2003; Pierce et al., 2007). Mossy cell feedback to granule cells, which normally is distributed distantly, might spread more locally to include nearby granule cells and thereby increase preservation of mossy cell-to-granule cell circuits in slices from epileptic rats.

There is at least one other potential hilar source of excitatory synaptic input to granule cells. Hilar ectopic granule cells normally are rare but develop after epileptogenic treatments (Parent et al., 1997; Scharfman et al., 2000) and occur in patients with temporal lobe epilepsy (Houser et al., 1990; Parent et al., 2006). They receive excitatory synaptic input from normotopic granule cells (Pierce et al., 2005) and extend axon collaterals into the dentate gyrus molecular layer (Cameron et al., 2011; Pierce et al., 
2011) where they could synapse with normotopic granule cells. Ectopic granule cells account for $34 \%$ of excitatory neurons in the hilus of epileptic pilocarpinetreated rats; mossy cells account for the rest (Jiao and Nadler, 2007). More work is needed to determine the respective contributions of ectopic granule cells and surviving mossy cells to aberrant positivefeedback circuits.

\section{Hilar ectopic granule cells}

Highly connected network hubs might contribute to seizure generation in the dentate gyrus (Morgan and Soltesz, 2008). Somata and proximal dendrites of ectopic granule cells are in the hilus where axons of mossy cells, CA3 pyramidal cells, and especially granule cells extend. Hilar ectopic granule cells have been proposed to be aberrant network hubs in part based on their expected high numbers of excitatory synaptic inputs (Cameron et al., 2011; Pierce et al., 2011). If so, one would predict higher hot-spot ratios in ectopic versus normotopic granule cells in epileptic rats. However, photostimulation revealed hot-spot ratios that were similar when stimulating the granule cell layer and CA3 pyramidal cell layer and were reduced when stimulating the hilus. Fewer hilar hot spots are consistent with smaller dendritic arbors in the inner molecular layer where mossy cell axons concentrate (Zhan et al., 2010). Similar granule cell layer hotspot ratios are consistent with similar EPSCs in normotopic and ectopic granule cells evoked by mossy fiber stimulation in epileptic rats (Zhan et al., 2010). Photostimulation results, therefore, do not support the hypothesis that hilar ectopic granule cells receive more excitatory synaptic input than normotopic granule cells in epileptic animals. However, we cannot exclude the possibility of additional sources of excitatory synaptic input from outside of the areas stimulated within $400-\mu \mathrm{m}$-thick slices used in the present study.

\section{Possible functional consequences}

Recurrent excitatory circuits can generate seizure-like activity (Wong et al., 1986), so it is reasonable to hypothesize that increased development of recurrent excitatory circuits might be epileptogenic. Results of the present study suggest CA3-togranule cell projections are developed excessively in epileptic pilocarpine-treated rats, which might convert a largely unidirectional circuit from the dentate gyrus to CA3 to one with potential to amplify signals from the dentate gyrus and to route activity from CA3 into the dentate gyrus (Scharfman, 2007). Excessive retrograde axonal projections might allow burst-firing CA3 pyramidal cells more direct access to the aberrant granule cell associative network, which might trigger seizure events among synaptically reorganized granule cells. In addition, findings of the present study are consistent with the possibility of increased
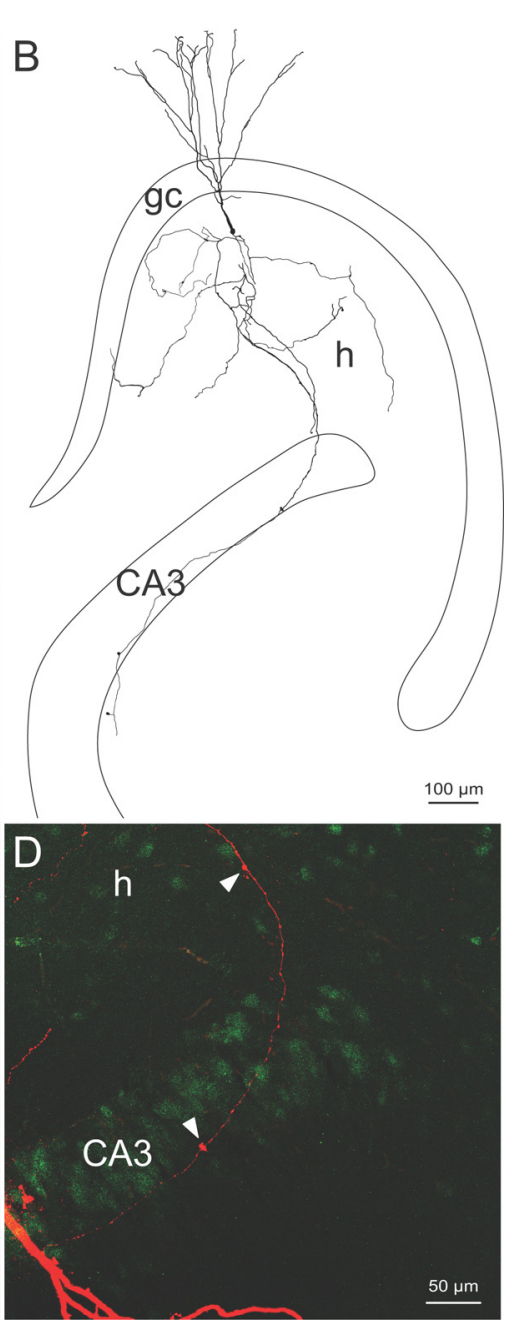

h

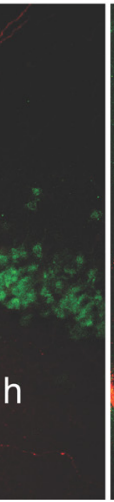

Figure 7. Hilar ectopic granule cells were identified by biocytin labeling. A, Biocytin-labeled hilar ectopic granule cell (arrow) and proximal CA3 pyramidal cell. The mossy fiber projection of the granule cell into CA3 is indicated by arrowheads. Borders of the ( (arrowheads) in the hilus and in stratum lucidum of CA3.

mossy cell feedback to nearby granule cells with similar potential consequences. Electrical stimulation in the proximal CA3 region or hilus can evoke seizure-like events in hippocampal slices from epileptic patients (Gabriel et al., 2004) and from laboratory animals (Patrylo and Dudek, 1998; Winokur et al., 2004), which has been attributed to mossy fiber sprouting. However, axon sprouting by CA3 pyramidal cells and mossy cells also could contribute. Indirect evidence suggests axon sprouting by mossy cells and CA3 pyramidal cells might compete with sprouting mossy fibers for postsynaptic sites on granule cell dendrites (Shetty et al., 2005). These findings might help explain the weak correlation between anatomically measured mossy fiber sprouting and seizure frequency (see Introduction).

Widespread epilepsy-related excitatory circuit reorganization Increasing evidence reveals widespread reorganization of excitatory circuits in epileptic brains. Mossy fiber sprouting by granule cells was detected over 30 years ago (Nadler et al., 1980) and might be the most dramatic example in part because of the retained potential for generating new granule cells in adults (Kron et al., 2010). Excitatory axon sprouting occurs in other hip- 

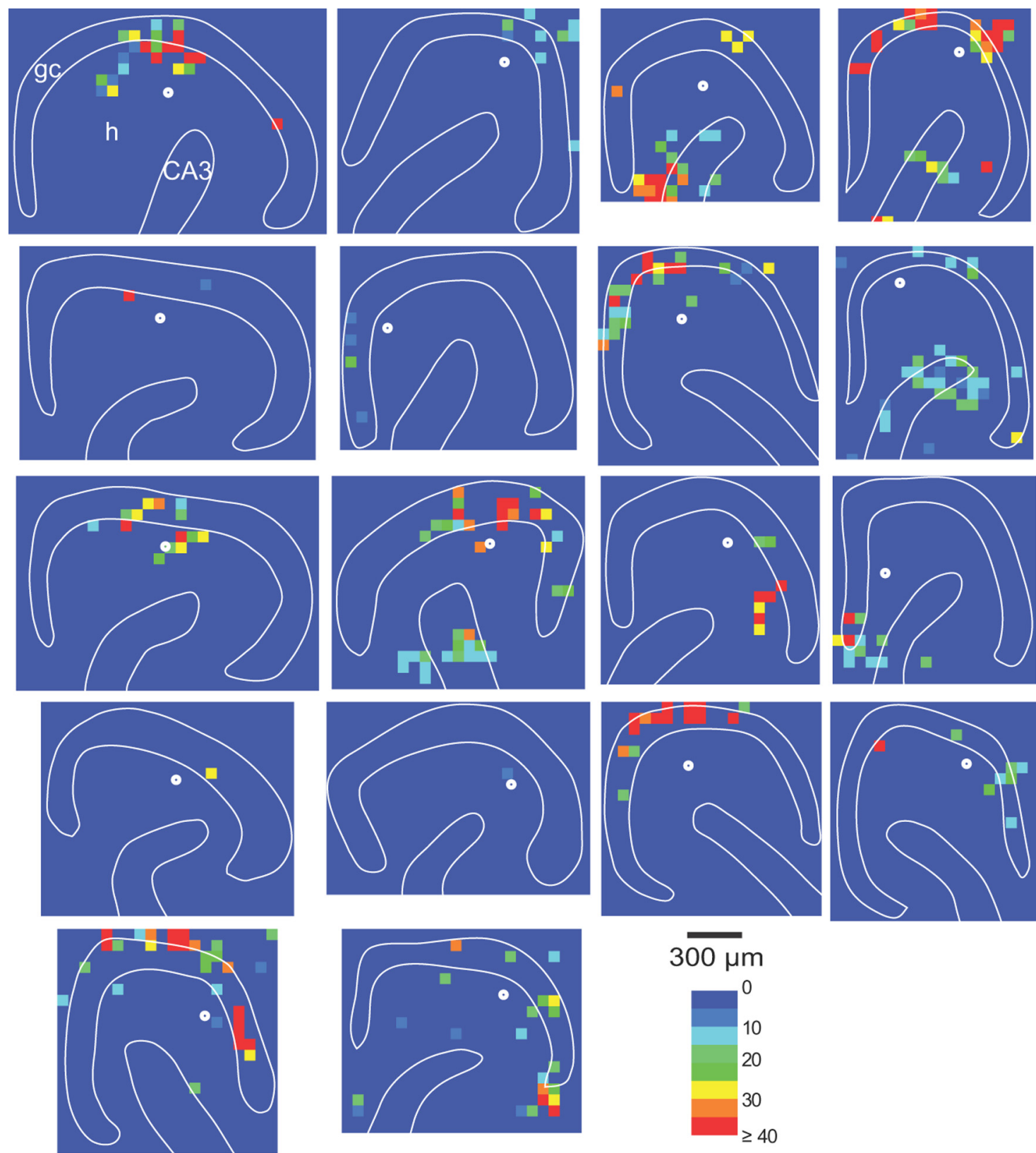

Figure 8. Connectivity maps of hilar ectopic granule cells based on composite amplitudes of glutamate photo-uncaging-evoked EPSCs in slices from epileptic rats. Sites of recorded hilar ectopic granule cells are indicated by white circles. gc, Granule cell layer; h, hilus; CA3, CA3 pyramidal cell layer.

pocampal regions of adult animals after epileptogenic injuries (Lehmann et al., 2001), including layer II entorhinal cortical input to dentate granule cells (Thind et al., 2010), CA3 associational connections (McKinney et al., 1997), CA3 projections to CA1, subiculum, and entorhinal cortex (Siddiqui and Joseph, 2005), CA1 input to other CA1 pyramidal cells (Perez et al., 1996; Esclapez et al., 1999; Smith and Dudek, 2002), and CA1 input to subiculum (Cavazos et al., 2004). Epileptogenic injuries in neocortex also cause excitatory axon sprouting (Salin et al., 1995; Jin et al., 2006). Clearly, development of excessive, recurrent, excitatory circuits is a common epilepsy-related abnormality.

\section{References}

Babb TL, Kupfer WR, Pretorius JK, Crandall PH, Levesque MF (1991) Synaptic reorganization by mossy fibers in human epileptic fascia dentata. Neuroscience 42:351-363.

Babb TL, Mathern GW, Leite JP, Pretorius JK, Yeoman KM, Kuhlman PA
(1996) Glutamate AMPA receptors in the fascia dentata of human and kainate rat hippocampal epilepsy. Epilepsy Res 26:193-205.

Benowitz LI, Routtenberg A (1997) GAP-43: an intrinsic determinant of neuronal development and plasticity. Trends Neurosci 20:84-91.

Blümcke I, Suter B, Behle K, Kuhn R, Schramm J, Elger CE, Wiestler OD (2000) Loss of hilar mossy cells in Ammon's horn sclerosis. Epilepsia 41 [Suppl 6]:S174-S180.

Brill J, Huguenard JR (2009) Robust short-latency perisomatic inhibition onto neocortical pyramidal cells detected by laser-scanning photostimulation. J Neurosci 29:7413-7423.

Buckmaster PS (2004) Laboratory animal models of temporal lobe epilepsy. Comp Med 54:473-485.

Buckmaster PS, Dudek FE (1997) Neuron loss, granule cell axon reorganization, and functional changes in the dentate gyrus of epileptic kainatetreated rats. J Comp Neurol 385:385-404.

Buckmaster PS, Jongen-Rêlo AL (1999) Highly specific neuron loss preserves lateral inhibitory circuits in the dentate gyrus of kainate-induced epileptic rats. J Neurosci 19:9519-9529. 
Buckmaster PS, Lew FH (2011) Rapamycin suppresses mossy fiber sprouting but not seizure frequency in a mouse model of temporal lobe epilepsy. J Neurosci 31:2337-2347.

Buckmaster PS, Strowbridge BW, Kunkel DD, Schmiege DL, Schwartzkroin PA (1992) Mossy cell axonal projections to the dentate gyrus molecular layer in the rat hippocampal slice. Hippocampus 2:349-362.

Buckmaster PS, Wenzel HJ, Kunkel DD, Schwartzkroin PA (1996) Axon arbors and synaptic connections of hippocampal mossy cells in the rat in vivo. J Comp Neurol 366:271-292.

Buckmaster PS, Zhang GF, Yamawaki R (2002) Axon sprouting in a model of temporal lobe epilepsy creates a predominantly excitatory feedback circuit. J Neurosci 22:6650-6658.

Cameron MC, Zhan RZ, Nadler JV (2011) Morphologic integration of hilar ectopic granule cells into dentate gyrus circuitry in the pilocarpine model of temporal lobe epilepsy. J Comp Neurol 519:2175-2192.

Cavazos JE, Jones SM, Cross DJ (2004) Sprouting and synaptic reorganization in the subiculum and CA1 region of the hippocampus in acute and chronic models of partial-onset epilepsy. Neuroscience 126:677-688.

Cronin J, Dudek FE (1988) Chronic seizures and collateral sprouting of dentate mossy fibers after kainic acid treatment in rats. Brain Res 474:181-184.

de Lanerolle NC, Kim JH, Robbins RJ, Spencer DD (1989) Hippocampal interneuron loss and plasticity in human temporal lobe epilepsy. Brain Res 495:387-395.

Del Turco D, Woods AG, Gebhardt C, Phinney AL, Jucker M, Frotscher M, Deller T (2003) Comparison of commissural sprouting in the mouse and rat fascia dentata after entorhinal cortex lesion. Hippocampus 13:685-699.

Esclapez M, Hirsch JC, Ben-Ari Y, Bernard C (1999) Newly formed excitatory pathways provide a substrate for hyperexcitability in experimental temporal lobe epilepsy. J Comp Neurol 408:449-460.

Fino E, Araya R, Peterka DS, Salierno M, Etchenique R, Yuste R (2009) RuBi-glutamate: two-photon and visible-light photoactivation of neurons and dendritic spines. Front Neural Circuits 3:2.

Franck JE, Pokorny J, Kunkel DD, Schwartzkroin PA (1995) Physiologic and morphologic characteristics of granule cell circuitry in human epileptic hippocampus. Epilepsia 36:543-558.

Gabriel S, Njunting M, Pomper JK, Merschhemke M, Sanabria ER, Eilers A, Kivi A, Zeller M, Meencke HJ, Cavalheiro EA, Heinemann U, Lehmann TN (2004) Stimulus and potassium-induced epileptiform activity in the human dentate gyrus from patients with and without hippocampal sclerosis. J Neurosci 24:10416-10430.

Golarai G, Greenwood AC, Feeney DM, Connor JA (2001) Physiological and structural evidence for hippocampal involvement in persistent seizure susceptibility after traumatic brain injury. J Neurosci 21:8523-8537.

Gorter JA, van Vliet EA, Aronica E, Lopes da Silva FH (2001) Progression of spontaneous seizures after status epilepticus is associated with mossy fibre sprouting and extensive bilateral loss of hilar parvalbumin and somatostatin-immunoreactive neurons. Eur J Neurosci 13:657-669.

Harvey BD, Sloviter RS (2005) Hippocampal granule cell activity and c-Fos expression during spontaneous seizures in awake, chronically epileptic, pilocarpine-treated rats: implications for hippocampal epileptogenesis. J Comp Neurol 488:442-463.

Houser CR, Miyashiro JE, Swartz BE, Walsh GO, Rich JR, Delgado-Escueta AV (1990) Altered patterns of dynorphin immunoreactivity suggest mossy fiber reorganization in human hippocampal epilepsy. J Neurosci 10:267-282.

Hunt RF, Scheff SW, Smith BN (2011) Synaptic reorganization of inhibitory hilar interneuron circuitry after traumatic brain injury in mice. J Neurosci 31:6880-6890.

Ishizuka N, Weber J, Amaral DG (1990) Organization of intrahippocampal projections originating from CA3 pyramidal cells in the rat. J Comp Neurol 295:580-623.

Jiao Y, Nadler JV (2007) Stereological analysis of GluR2-immunoreactive hilar neurons in the pilocarpine model of temporal lobe epilepsy: correlation of cell loss with mossy fiber sprouting. Exp Neurol 205:569-582.

Jin X, Huguenard JR, Prince DA (2005) Impaired $\mathrm{Cl}^{-}$extrusion in layer V pyramidal neurons of chronically injured epileptogenic neocortex. J Neurophysiol 93:2117-2126.
Jin X, Prince DA, Huguenard JR (2006) Enhanced excitatory synaptic connectivity in layer $\mathrm{V}$ pyramidal neurons of chronically injured epileptogenic neocortex in rats. J Neurosci 26:4891-4900.

Jung KH, Chu K, Kim M, Jeong SW, Song YM, Lee ST, Kim JY, Lee SK, Roh JK (2004) Continuous cytosine-b-D-arabinofuranoside infusion reduces ectopic granule cells in adult rat hippocampus with attenuation of spontaneous recurrent seizures following pilocarpine-induced status epilepticus. Eur J Neurosci 19:3219-3226.

Kadam SD, Dudek FE (2007) Neuropathological features of a rat model for perinatal hypoxic-ischemic encephalopathy with associated epilepsy. J Comp Neurol 505:716-737.

Kharatishvili I, Nissinen JP, McIntosh TK, Pitkänen A (2006) A model of posttraumatic epilepsy induced by lateral fluid-percussion brain injury in rats. Neuroscience 140:685-697.

Kneisler TB, Dingledine R (1995) Synaptic input from CA3 pyramidal cells to dentate basket cells in rat hippocampus. J Physiol 487:125-146.

Kobayashi M, Buckmaster PS (2003) Reduced inhibition of dentate granule cells in a model of temporal lobe epilepsy. J Neurosci 23:2440-2452.

Kron MM, Zhang H, Parent JM (2010) The developmental stage of dentate granule cells dictates their contribution to seizure-induced plasticity. J Neurosci 30:2051-2059.

Kumar SS, Jin X, Buckmaster PS, Huguenard JR (2007) Recurrent circuits in layer II of medial entorhinal cortex in a model of temporal lobe epilepsy. J Neurosci 27:1239-1246.

Larimer P, Strowbridge BW (2008) Nonrandom local circuits in the dentate gyrus. J Neurosci 28:12212-12223.

Lehmann TN, Gabriel S, Eilers A, Njunting M, Kovacs R, Schulze K, Lanksch WR, Heinemann U (2001) Fluorescent tracer in pilocarpine-treated rats shows widespread aberrant hippocampal neuronal connectivity. Eur J Neurosci 14:83-95.

Lemos T, Cavalheiro EA (1995) Suppression of pilocarpine-induced status epilepticus and the late development of epilepsy in rats. Exp Brain Res 102:423-428.

Li XG, Somogyi P, Ylinen A, Buzsáki G (1994) The hippocampal CA3 network: an in vivo intracellular labeling study. J Comp Neurol 339:181-208.

Lynch M, Sutula T (2000) Recurrent excitatory connectivity in the dentate gyrus of kindled and kainic acid-treated rats. J Neurophysiol 83:693-704.

Lynd-Balta E, Pilcher WH, Joseph SA (2004) AMPA receptor alterations precede mossy fiber sprouting in young children with temporal lobe epilepsy. Neuroscience 126:105-114.

Masukawa LM, Uruno K, Sperling M, O’Connor MJ, Burdette LJ (1992) The functional relationship between antidromically evoked field responses of the dentate gyrus and mossy fiber reorganization in temporal lobe epileptic patients. Brain Res 579:119-127.

Mathern GW, Cifuentes F, Leite JP, Pretorius JK, Babb TL (1993) Hippocampal EEG excitability and chronic spontaneous seizures are associated with aberrant synaptic reorganization in the rat intrahippocampal kainate model. Electroencephalogr Clin Neurophysiol 87:326-339.

Mathern GW, Bertram EH 3rd, Babb TL, Pretorius JK, Kuhlman PA, Spradlin S, Mendoza D (1997) In contrast to kindled seizures, the frequency of spontaneous epilepsy in the limbic status model correlates with greater aberrant fascia dentata excitatory and inhibitory axon sprouting, and increased staining for $N$-methyl-D-aspartate, AMPA and $\mathrm{GABA}_{\mathrm{A}}$ receptors. Neuroscience 77:1003-1019.

Mathern GW, Pretorius JK, Mendoza D, Lozada A, Kornblum HI (1998) Hippocampal AMPA and NMDA mRNA levels correlate with aberrant fascia dentata mossy fiber sprouting in the pilocarpine model of spontaneous limbic epilepsy. J Neurosci Res 54:734-753.

McKinney RA, Debanne D, Gähwiler BH, Thompson SM (1997) Lesioninduced axonal sprouting and hyperexcitability in the hippocampus in vitro: implications for the genesis of posttraumatic epilepsy. Nat Med 3:990-996.

Mello LE, Cavalheiro EA, Tan AM, Kupfer WR, Pretorius JK, Babb TL, Finch DM (1993) Circuit mechanisms of seizures in the pilocarpine model of chronic epilepsy: cell loss and mossy fiber sprouting. Epilepsia 34:985-995.

Mody I, Heinemann U (1987) NMDA receptors of dentate gyrus granule cells participate in synaptic transmission following kindling. Nature 326:701-704. 
Molnár P, Nadler JV (1999) Mossy fiber-granule cell synapses in the normal and epileptic rat dentate gyrus studied with minimal laser photostimulation. J Neurophysiol 82:1883-1894.

Morgan RJ, Soltesz I (2008) Nonrandom connectivity of the epileptic dentate gyrus predicts a major role for neuronal hubs in seizures. Proc Natl Acad Sci U S A 105:6179-6184.

Nadler JV, Perry BW, Cotman CW (1980) Selective reinnervation of hippocampal area CA1 and the fascia dentata after destruction of CA3-CA4 afferents with kainic acid. Brain Res 182:1-9.

Namgung U, Matsuyama S, Routtenberg A (1997) Long-term potentiation activates the GAP-43 promoter: selective participation of hippocampal mossy cells. Proc Natl Acad Sci U S A 94:11675-11680.

Nissinen J, Lukasiuk K, Pitkänen A (2001) Is mossy fiber sprouting present at the time of the first spontaneous seizures in rat experimental temporal lobe epilepsy? Hippocampus 11:299-310.

Parent JM, Yu TW, Leibowitz RT, Geschwind DH, Sloviter RS, Lowenstein DH (1997) Dentate granule cell neurogenesis is increased by seizures and contributes to aberrant network reorganization in the adult rat hippocampus. J Neurosci 17:3727-3738.

Parent JM, Elliott RC, Pleasure SJ, Barbaro NM, Lowenstein DH (2006) Aberrant seizure-induced neurogenesis in experimental temporal lobe epilepsy. Ann Neurol 59:81-91.

Patrylo PR, Dudek FE (1998) Physiological unmasking of new glutamatergic pathways in the dentate gyrus of hippocampal slices from kainateinduced epileptic rats. J Neurophysiol 79:418-429.

Perez Y, Morin F, Beaulieu C, Lacaille JC (1996) Axonal sprouting of CA1 pyramidal cells in hyperexcitable hippocampal slices of kainate-treated rats. Eur J Neurosci 8:736-748.

Pierce JP, Melton J, Punsoni M, McCloskey DP, Scharfman HE (2005) Mossy fibers are the primary source of afferent input to ectopic granule cells that are born after pilocarpine-induced seizures. Exp Neurol 196:316-331.

Pierce JP, Punsoni M, McCloskey DP, Scharfman HE (2007) Mossy cell axon synaptic contacts on ectopic granule cells that are born following pilocarpine-induced seizures. Neurosci Lett 422:136-140.

Pierce JP, McCloskey DP, Scharfman HE (2011) Morphometry of hilar ectopic granule cells in the rat. J Comp Neurol 519:1196-1218.

Pitkänen A, Nissinen J, Lukasiuk K, Jutila L, Paljarvi L, Salmenpera T, Karkola K, Vapalahti M, Ylinen A (2000) Association between the density of mossy fiber sprouting and seizure frequency in experimental and human temporal lobe epilepsy. Epilepsia 41 [Suppl 6]:S24-S29.

Pitkänen A, Kharatishvili I, Narkilahti S, Lukasiuk K, Nissinen J (2005) Administration of diazepam during status epilepticus reduces development and severity of epilepsy in rat. Epilepsy Res 63:27-42.

Prang P, Del Turco D, Deller T (2003) Associational sprouting in the mouse fascia dentata after entorhinal lesion in vitro. Brain Res 978:205-212.

Prince DA, Tseng GF (1993) Epileptogenesis in chronically injured cortex: in vitro studies. J Neurophysiol 69:1276-1291.

Racine RJ (1972) Modification of seizure activity by electrical stimulation. II. Motor seizure. Electroencephalogr Clin Neurophysiol 32:281-294.

Rao MS, Hattiangady B, Reddy DS, Shetty AK (2006) Hippocampal neurodegeneration, spontaneous seizures, and mossy fiber sprouting in the F344 rat model of temporal lobe epilepsy. J Neurosci Res 83:1088-1105.

Raol YS, Budreck EC, Brooks-Kayal AR (2003) Epilepsy after early-life seizures can be independent of hippocampal injury. Ann Neurol 53:503-511.

Represa A, Jorquera I, Le Gal La Salle G, Ben-Ari Y (1993) Epilepsy induced collateral sprouting of hippocampal mossy fibers: does it induce the development of ectopic synapses with granule cell dendrites? Hippocampus 3:257-268.

Salin P, Tseng GF, Hoffman S, Parada I, Prince DA (1995) Axonal sprouting in layer $\mathrm{V}$ pyramidal neurons of chronically injured cerebral cortex. J Neurosci 15:8234-8245.

Santhakumar V, Ratzliff AD, Jeng J, Toth Z, Soltesz I (2001) Long-term hyperexcitability in the hippocampus after experimental head trauma. Ann Neurol 50:708-717.

Scharfman HE (1994) Evidence from simultaneous intracellular recordings in rat hippocampal slices that area CA3 pyramidal cells innervate dentate hilar mossy cells. J Neurophysiol 72:2167-2180.

Scharfman HE (1995) Electrophysiological evidence that dentate hilar mossy cells are excitatory and innervate both granule cells and interneurons. J Neurophysiol 74:179-194.

Scharfman HE (2007) The CA3 "backprojection" to the dentate gyrus. Prog Brain Res 163:627-637.

Scharfman HE, Kunkel DD, Schwartzkroin PA (1990) Synaptic connections of dentate granule cells and hilar neurons: results of paired intracellular recordings and intracellular horseradish peroxidase injections. Neuroscience 37:693-707.

Scharfman HE, Goodman JH, Sollas AL (2000) Granule-like neurons at the hilar/CA3 border after status epilepticus and their synchrony with area CA3 pyramidal cells: functional implications of seizure-induced neurogenesis. J Neurosci 20:6144-6158.

Scharfman HE, Sollas AL, Berger RE, Goodman JH (2003) Electrophysiological evidence of monosynaptic excitatory transmission between granule cells after seizure-induced mossy fiber sprouting. J Neurophysiol 90:2536-2547.

Seress L, Abrahám H, Horváth Z, Dóczi T, Janszky J, Klemm J, Byrne R, Bakay RA (2009) Survival of mossy cells of the hippocampal dentate gyrus in humans with mesial temporal lobe epilepsy. J Neurosurg 111:1237-1247.

Shepherd GM, Pologruto TA, Svoboda K (2003) Circuit analysis of experience-dependent plasticity in the developing rat barrel cortex. Neuron 38:277-289.

Shetty AK, Zaman V, Hattiangady B (2005) Repair of the injured adult hippocampus through graft-mediated modulation of the plasticity of the dentate gyrus in a rat model of temporal lobe epilepsy. J Neurosci 25:8391-8401.

Siddiqui AH, Joseph SA (2005) CA3 axonal sprouting in kainate-induced chronic epilepsy. Brain Res 1066:129-146.

Sík A, Coté A, Boldogkõi Z (2006) Selective spread of neurotropic herpesviruses in the rat hippocampus. J Comp Neurol 496:229-243.

Simmons ML, Terman GW, Chavkin C (1997) Spontaneous excitatory currents and kappa-opioid receptor inhibition in dentate gyrus are increased in the rat pilocarpine model of temporal lobe epilepsy. J Neurophysiol $78: 1860-1868$.

Sloviter RS (1992) Possible functional consequences of synaptic reorganization in the dentate gyrus of kainate-treated rats. Neurosci Lett 137:91-96.

Smith BN, Dudek FE (2002) Network interactions mediated by new excitatory connections between CA1 pyramidal cells in rats with kainateinduced epilepsy. J Neurophysiol 87:1655-1658.

Spencer SS, Kim J, de Lanerolle N, Spencer DD (1999) Differential neuronal and glial relations with parameters of ictal discharge in mesial temporal lobe epilepsy. Epilepsia 40:708-712.

Spigelman I, Yan XX, Obenaus A, Lee EY, Wasterlain CG, Ribak CE (1998) Dentate granule cells form novel basal dendrites in a rat model of temporal lobe epilepsy. Neuroscience 86:109-120.

Sutula T, Cascino G, Cavazos J, Parada I, Ramirez L (1989) Mossy fiber synaptic reorganization in the epileptic human temporal lobe. Ann Neurol 26:321-330.

Thind KK, Ribak CE, Buckmaster PS (2008) Synaptic input to dentate granule cell basal dendrites in a rat model of temporal lobe epilepsy. J Comp Neurol 509:190-202.

Thind KK, Yamawaki R, Phanwar I, Zhang G, Wen X, Buckmaster PS (2010) Initial loss but later excess of GABAergic synapses with dentate granule cells in a rat model of temporal lobe epilepsy. J Comp Neurol 518:647-667.

Timofeeva OA, Peterson GM (1999) Dissociation of mossy fiber sprouting and electrically-induced seizure sensitivity: rapid kindling versus adaptation. Epilepsy Res 33:99-115.

von Campe G, Spencer DD, de Lanerolle NC (1997) Morphology of dentate granule cells in the human epileptogenic hippocampus. Hippocampus 7:472-488.

Wenzel HJ, Born DE, Dubach MF, Gundersen VM, Maravilla KR, Robbins CA, Szot P, Zierath D, Schwartzkroin PA (2000a) Morphological plasticity in an infant monkey model of temporal lobe epilepsy. Epilepsia 41 [Suppl 6]:S70-S75.

Wenzel HJ, Woolley CS, Robbins CA, Schwartzkroin PA (2000b) Kainic acid-induced mossy fiber sprouting and synapse formation in the dentate gyrus of rats. Hippocampus 10:244-260.

Williams PA, Dou P, Dudek FE (2004) Epilepsy and synaptic reorganization in a perinatal rat model of hypoxia-ischemia. Epilepsia 45:1210-1218. 
Winokur RS, Kubal T, Liu D, Davis SF, Smith BN (2004) Recurrent excitation in the dentate gyrus of a murine model of temporal lobe epilepsy. Epilepsy Res 58:93-105.

Wong RK, Traub RD, Miles R (1986) Cellular basis of neuronal synchrony in epilepsy. Adv Neurol 44:583-592.

Wuarin JP, Dudek FE (1996) Electrographic seizures and new recurrent excitatory circuits in the dentate gyrus of hippocampal slices from kainatetreated epileptic rats. J Neurosci 16:4438-4448.

Wuarin JP, Dudek FE (2001) Excitatory synaptic input to granule cells increases with time after kainate treatment. J Neurophysiol 85:1067-1077.

Zhan RZ, Timofeeva O, Nadler JV (2010) High ratio of synaptic excitation to synaptic inhibition in hilar ectopic granule cells of pilocarpine-treated rats. J Neurophysiol 104:3293-3304.

Zhang N, Houser CR (1999) Ultrastructural localization of dynorphin in the dentate gyrus in human temporal lobe epilepsy: a study of reorganized mossy fiber synapses. J Comp Neurol 405:472-490.

Zhang W, Yamawaki R, Wen X, Uhl J, Diaz J, Prince DA, Buckmaster PS (2009) Surviving hilar somatostatin interneurons enlarge, sprout axons, and form new synapses with granule cells in a mouse model of temporal lobe epilepsy. J Neurosci 29:14247-14256.

Zhang X, Cui SS, Wallace AE, Hannesson DK, Schmued LC, Saucier DM, Honer WG, Corcoran ME (2002) Relations between brain pathology and temporal lobe epilepsy. J Neurosci 22:6052-6061. 